\title{
Unexpected coseismic surface uplift at Tirúa-Mocha Island area of south Chile before and during the Mw 8.8 Maule 2010 earthquake: a possible upper plate splay fault
}

\author{
Jorge Quezada ${ }^{1}$, Edilia Jaque ${ }^{2}$, Nicole Catalán ${ }^{1}$, Arturo Belmonte ${ }^{3}$, \\ Alfonso Fernández ${ }^{2}$, Federico Isla ${ }^{4}$
}

\author{
1 Departamento de Ciencias de la Tierra, Facultad de Ciencias Químicas, Universidad de Concepción, Victor Lamas 1290, Casilla 160-C, \\ Concepción, Chile. \\ jquezad@udec.cl; nicolecatalan@udec.cl \\ 2 Departamento de Geografia, Facultad de Arquitectura, Urbanismo y Geografia, Universidad de Concepción, Víctor Lamas 1290, Casilla 160-C, \\ Concepción, Chile. \\ edjaque@udec.cl; alfernandez@udec.cl \\ 3 Departamento de Geofisica, Facultad de Ciencias Físicas y Matemáticas, Universidad de Concepción, Victor Lamas 1290, Casilla 160-C, \\ Concepción, Chile. \\ abelmonte@dgeo.udec.cl \\ ${ }^{4}$ Instituto de Geología de Costas y del Cuaternario (UNMDP-CIC), Instituto de Investigaciones Marinas y Costeras (CONICET-UNMDP), \\ Deán Funes 3350, Mar del Plata, Argentina. \\ fisla@mdp.edu.ar
}

\begin{abstract}
The Tirúa-Mocha Island area $\left(38.2^{\circ}-38.4^{\circ} \mathrm{S}\right)$ in southern Chile has been affected by two megaearthquakes in only 50 years: the $1960 \mathrm{Mw}=9.5$ Valdivia earthquake and $2010 \mathrm{Mw}=8.8 \mathrm{Maule}$ earthquake. We studied in the field the vertical ground movements occurred during the interseismic period between both earthquakes and the coseismic period of 2010 Maule earthquake and $2011 \mathrm{Mw}=7.1$ Araucanía earthquake. During the 1960 earthquake, vertical coseismic ground movements are typical of subduction related earthquakes with Mocha Island, located close to the trench, experienced bigger ground uplift $(150 \mathrm{~cm})$ than that occurred in Tirúa $(-20 \mathrm{~cm})$, place located in the continental margin at the latitude of Mocha Island. Then during the 1960-2010 interseismic period, the 1960 coseismic uplift remained at Mocha Island unlike the normal interseismic subsidence that occurred northward at Arauco Peninsula and Santa María Island. Also Tirúa experienced the biggest interseismic uplift $(180 \mathrm{~cm})$ in all the area affected later by 2010 Maule earthquake. Then during the $2010 \mathrm{Mw}=8.8$ Maule earthquake an anomalous vertical coseismic ground uplift occurred in the study area, opposite to that of 1960 since Mocha Island experienced lower $(25 \mathrm{~cm})$ ground uplift than Tirúa $(90 \mathrm{~cm})$. Subsequently, during the Araucanía 2011 earthquake a ground uplift in Mocha Island $(50 \mathrm{~cm})$ and subsidence at Tirúa $(20 \mathrm{~cm})$ occurred. These unexpected vertical ground movements can be explained by the existence of an upper plate splay fault located below the sea bottom between Tirúa and Mocha Island: the Tirúa-Mocha splay fault. Considering the last seismic cycle, the activity of this fault would have started after the 1960 Valdivia earthquake. During 2010 Maule earthquake, the main slip occurred at Tirúa Mocha splay fault. Finally during 2011 Araucanía earthquake, the slip occurred mainly at the updip of Wadati-Benioff plane with probable normal activity of Tirúa-Mocha splay fault. Simple elastic dislocation models considering the Wadati-Benioff plane and the Tirúa-Mocha splay fault activity, can account for all the vertical ground movements observed during 1960 earthquake, the 1960-2010 interseismic period, the 2010 Maule earthquake and the 2011 Araucanía earthquake.
\end{abstract}


RESUMEN. Alzamiento cosísmico superficial inesperado en el área de Tirúa-isla Mocha del sur de Chile antes y durante el terremoto de Maule $M w=8,8$ de 2010: una probable falla subsidiaria en la placa superior. El área de Tirúa-Isla Mocha $\left(38,2^{\circ} \mathrm{S}-38,4^{\circ} \mathrm{S}\right)$ ubicada en el sur de Chile ha sido afectada por dos megaterremotos en solo 50 años: el terremoto de Valdivia Mw=9,5 de 1960 y el terremoto del Maule Mw=8,8 de 2010. Se estudiaron en el campo los movimientos verticales del terreno asociados al período intersísmico entre estos terremotos y los cosísmicos relacionados con los terremotos del Maule 2010 y Araucanía 2011 Mw=7,1. Durante el terremoto de 1960, los movimientos cosísmicos verticales del terreno fueron los esperados, ya que la isla Mocha, localizada cerca de la fosa experimentó mayor alzamiento $(150 \mathrm{~cm})$ que Tirúa $(-20 \mathrm{~cm})$, localidad situada en el margen continental frente a esta isla. Luego, durante el período intersísmico (1960-2010), el alzamiento cosísmico de 1960 permaneció en la isla Mocha a diferencia de la subsidencia intersísmica normal que ocurrió más al norte en la península de Arauco e isla Santa María. Además, Tirúa experimentó la mayor tasa de alzamiento intersísmico $(180 \mathrm{~cm})$ en el área afectada posteriormente por el terremoto de Maule de 2010. Después en el terremoto del Maule $\mathrm{Mw}=8,8$ de 2010, ocurrió un alzamiento cosísmico vertical anómalo opuesto al de 1960, donde la isla Mocha experimentó menor alzamiento $(25 \mathrm{~cm})$ que Tirúa $(90 \mathrm{~cm})$. Más tarde durante el terremoto de Araucanía del año 2011, ocurrió un alzamiento del terreno en isla Mocha (50 cm) y subsidencia en Tirúa (20 cm). Estas anomalías pueden ser explicadas por la existencia de una falla subsidiaria en la placa superior, localizada bajo el piso oceánico entre Tirúa y la Isla Mocha: la falla subsidiaria Tirúa-Mocha. Considerando el último ciclo sísmico, la actividad de esta falla habría comenzado después del terremoto de Valdivia de 1960. Durante el terremoto de Maule de 2010, el deslizamiento principal ocurrió en la falla subsidiaria Tirúa-Mocha. Finalmente durante el terremoto de Araucanía de 2011, el deslizamiento ocurrió principalmente en la parte superior del plano de Wadati-Benioff con probable actividad normal de la falla subsidiaria Tirúa-Mocha. Modelos de dislocación elástica simples, considerando el plano de Wadati-Benioff y la falla subsidiaria de Tirúa-Mocha y su actividad, explican todos los movimientos verticales del período intersísmico 1960-2010, y los cosísmicos de los terremotos del Maule del 2010 y Araucanía del 2011.

Palabras clave: Alzamiento anómalo, Falla subsidiaria, Wadati, Benioff, Terremoto del Maule 2010, Terremoto de Araucanía 2011, Tirua, Isla Mocha, Chile.

\section{Introduction}

The occurrence of upper plate splay faults in the outer forearc is common to subduction zones. These faults are commonly reverse and branch towards the surface from the main subduction fault plane with same vergence, higher dip angle and mainly accommodate the deformation of the accretionary prism or close to it. Splay faults in subduction zones have been documented from seismic profiles at the Nankai Through of Japan (Moore et al., 2007; Strasser et al., 2009; Gulick et al., 2010), Colombia-Ecuador (Collot et al., 2008), Alaska (Liberty et al., 2013) and Iran-Makran subduction zones (Heidarzadeh, 2011). During subduction earthquakes, splay faults can accommodate part of the coseismic slip (Fukao, 1979; Cummins et al., 2001; Tamura and Ide, 2011; De Dontney and Hubbard, 2012; Li et al., 2014; Wendt et al., 2009). One remarkable case resulted from the $\mathrm{Mw}=9.21964$ Alaska earthquake, where the Patton Bay and Hanning Bay reverse faults at Montague Island, generated an additional coseismic uplift which was recorded in the visible pattern of fault scarps (Plafker, 1972). Other visible splay fault is the Chelungpu Fault, reactivated during the 1999 Taiwan Chi-Chi earthquake (Lee et al., 2002). Several splay fault also had visible scarps during the New
Zealand $\mathrm{Mw}=7.8$ Kaikoura earthquake (Hollingsworth et al., 2017; Wang et al., 2018). It is also mentioned that similar faults were reactivated during the 2004 $\mathrm{Mw}=9.3$ Sumatra earthquake (Hoechner et al., 2008; Plafker et al., 2007; Plafker and Savage, 2010; Heidarzadeh, 2011; Wadhauser et al., 2012). Because the uplift generated by splay faults, they are potential source of tsunamis (Moore et al., 2007; Plafker et al., 2007; Wendt et al., 2009; Plafker and Savage, 2010; Heidarzadeh, 2011; Wang et al., 2018). Splay faults have also caused additional coastal uplift, as evidenced by the high position of Holocene marine terraces in New Zealand, Papua New Guinea, Taiwan and Japan (Ota and Yamaguchi, 2004), Philippines (Ramos and Tsutsumi, 2010), Myanmar (Shyu et al., 2014), Greece (Tiberti et al., 2014) and Alaska (Plafker and Rubin, 1998; Savage et al., 2014).

In Chile, the subduction of Nazca Plate beneath South American one at $64-79 \mathrm{~mm} / \mathrm{yr}, \mathrm{N} 77^{\circ} \mathrm{E}$ trend and NE direction (Angermann et al., 1999) from Arica Bend to Taitao Peninsula $\left(18.5^{\circ} \mathrm{S}-47^{\circ} \mathrm{S}\right)$, has generated large earthquakes and tsunamis in south Chile such as Concepción 1835, Valdivia 1960 $\mathrm{Mw}=9.5$ and Maule $2010 \mathrm{Mw}=8.8$ earthquakes. For Maule 2010 earthquake, different rupture zone lengths (450-650 km) have been suggested (Farías et al., 2010; Delouis et al., 2010; Lay et al., 2010; 
Sparkes et al., 2010; Tong et al., 2010; Xue et al., 2010; Vargas et al., 2011; Vigny et al., 2011). In this work a rupture length of $640 \mathrm{~km}$ is considered, from $33^{\circ} \mathrm{S}$ to $38.6^{\circ} \mathrm{S}$ (Fig. 1), taking into account the distribution of earlier aftershocks and evidences of vertical coastal changes (Quezada et al., 2012). For most of the seismic rupture zone, a theoretically expected coseismic trend of deformation occurred with a decreasing uplift from trench to arc (Farías et al., 2010; Quezada et al., 2010; Vargas et al., 2011;

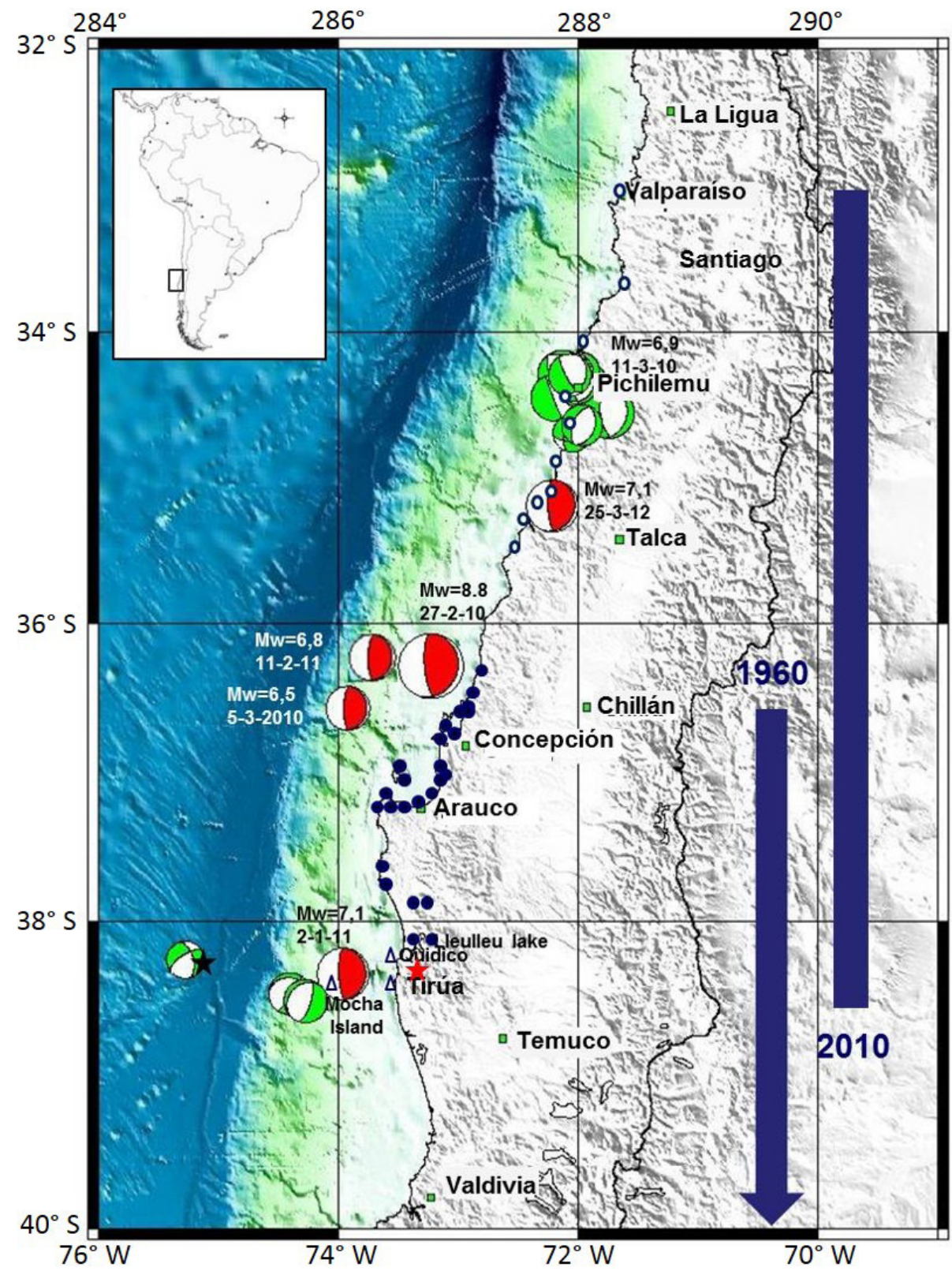

FIG. 1. Location map. Focal mechanisms of some strong aftershocks of Maule 2010 earthquake are shown. Maule 2010 earthquake epicentre came from CSN (Centro Sismológico Nacional, Universidad de Chile), January $2^{\text {nd }} 2011$ event is relocated by CSN at the NW tip of Mocha Island, illustrated by the position of the focal mechanism. For This event, black star are the original location of CSN and red star NEIC one. Red focal mechanisms are thrust and green ones, normal. Locations where vertical changes of Maule earthquake were measured are indicated: white circles for northern segment, blue circles for southern segment and triangles for Tirúa-Mocha zone. Blue bars represent the extension of the rupture zones of 1960 and 2010 earthquakes. 
Vigny et al., 2011, Fig. 2). This trend indicates that the main slip occurred along the Wadati-Benioff plane. Nevertheless, during the Maule 2010 earthquake, in the southermost part of the rupture zone, between $38.2^{\circ} \mathrm{S}$ and $38.4^{\circ} \mathrm{S}$, an unexpected coseismic uplift trend occurred since Mocha Island located close to the trench, experienced a lesser uplift than Tirúa area, located at the coastline in front of it (Farías et al., 2010; Quezada et al., 2010; Melnick et al., 2012), as shown in figure 2 . The tsunami produced by the Maule 2010 earthquake had its highest run up at Mocha Island, being higher than $20 \mathrm{~m}$, with the first tsunami wave that arrived half an hour after the earthquake (Fritz et al., 2011). Also, this zone was affected by one of the two biggest aftershocks of Maule 2010 earthquake, the $\mathrm{Mw}=7.1$ Araucanía earthquake of January $2^{\text {nd }} 2011$ (Fig. 1). Other significant aftershocks at Tirúa-Mocha Island area occurred on May $3^{\text {rd }} 2010(\mathrm{Mw}=6.3)$ and July $14^{\text {th }}$
$2010(\mathrm{Mw}=6.6)$. This zone was also affected by the Concepción 1835 earthquake which generated $0.6 \mathrm{~m}$ uplift at Mocha Island, $1.8 \mathrm{~m}$ in Arauco Peninsula and 2.4-3 $\mathrm{m}$ at Santa María Island (Fitz-Roy, 1839; Pizarro, 1991; Wesson et al., 2015); and the Valdivia $1960 \mathrm{Mw}=9.5$ earthquake that generated 0.7-1.3 m uplift in Arauco Peninsula, $1.5-1.8 \mathrm{~m}$ at Mocha Island and $0.2 \mathrm{~m}$ subsidence in Tirúa (Veyl, 1960; Saint Amand, 1961; Plafker and Savage, 1970; Plafker, 1972; Nelson and Manley, 1992). In addition, the highest Holocene marine terrace at Mocha Island is located at $33 \mathrm{~m}$ a.s.l. (before Maule earthquake), suggesting an uplift rate of $20 \mathrm{~mm} / \mathrm{yr}$ for the last 1,000 years (Nelson and Manley, 1992). These features in the southernmost rupture zone of Maule 2010 earthquake at TirúaMocha Island $\left(38.2^{\circ} \mathrm{S}-38.4^{\circ} \mathrm{S}\right)$ area, may indicate the existence of a splay fault activity triggered by some subduction earthquakes.

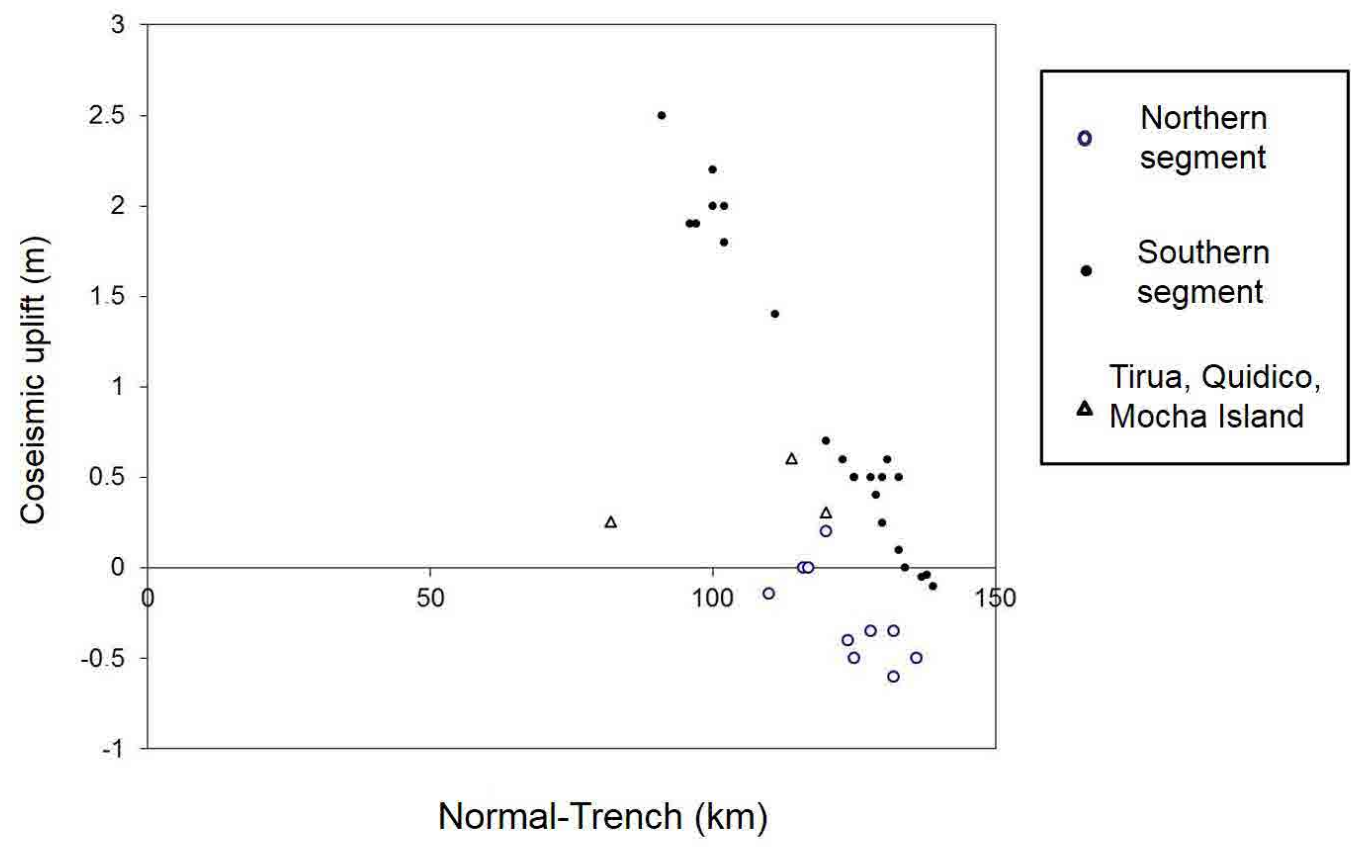

FIG. 2. Vertical coseismic ground movements trend for Maule 2010 earthquake. Northern segment: points from $33^{\circ} \mathrm{S}-35.5^{\circ} \mathrm{S}$, southern segment points from $36^{\circ} \mathrm{S}-38.2^{\circ} \mathrm{S}$, data from Quezada et al. (2010) location is showed in figure 1 . The different normal trench distance of cero uplift in both segments indicates the shallower rupture of northern segment. The anomalous behavior of of Tirúa-Mocha Island and Quidico area (two points, one is the same of Tirúa, the other is the rock located $2.2 \mathrm{~km}$ north Quidico), is shown by a lesser surface uplift at Mocha Island than Tirúa. 
The aim of this work is to evaluate the existence of this probable subduction zone splay fault at the Mocha Island-Tirúa area and if it was active during the last subduction seismic cycle (Fig. 3).

\section{Methodology}

With the purpose to evaluate the probable activity of the Mocha Island-Tirúa splay fault, we conducted three fieldwork campaigns at Arauco Peninsula, Mocha Island and Santa María Island (Fig. 3): 1) before the Maule Earthquake (2007-2009), 2) after Maule Earthquake (March-October 2010) and 3) after the Araucanía earthquake (January $20^{\text {th }}$ 2011). Coastal geomorphic changes were considered; natural and anthropomorphic markers of the sea level were interpreted accordingly. In addition, elastic dislocation models based on the Okada (1992) equations were run to test the existence of movements only along the Wadati-Benioff zone, or assuming an upper plate splay fault: it location, activity, geometry and slip considering the vertical changes produced during Valdivia 1960 and Maule 2010 earthquakes, the interseismic time between both, and the Araucanía 2011 earthquake. The uncertainty of our measurements and cited data are $\pm 10 \mathrm{~cm}$.

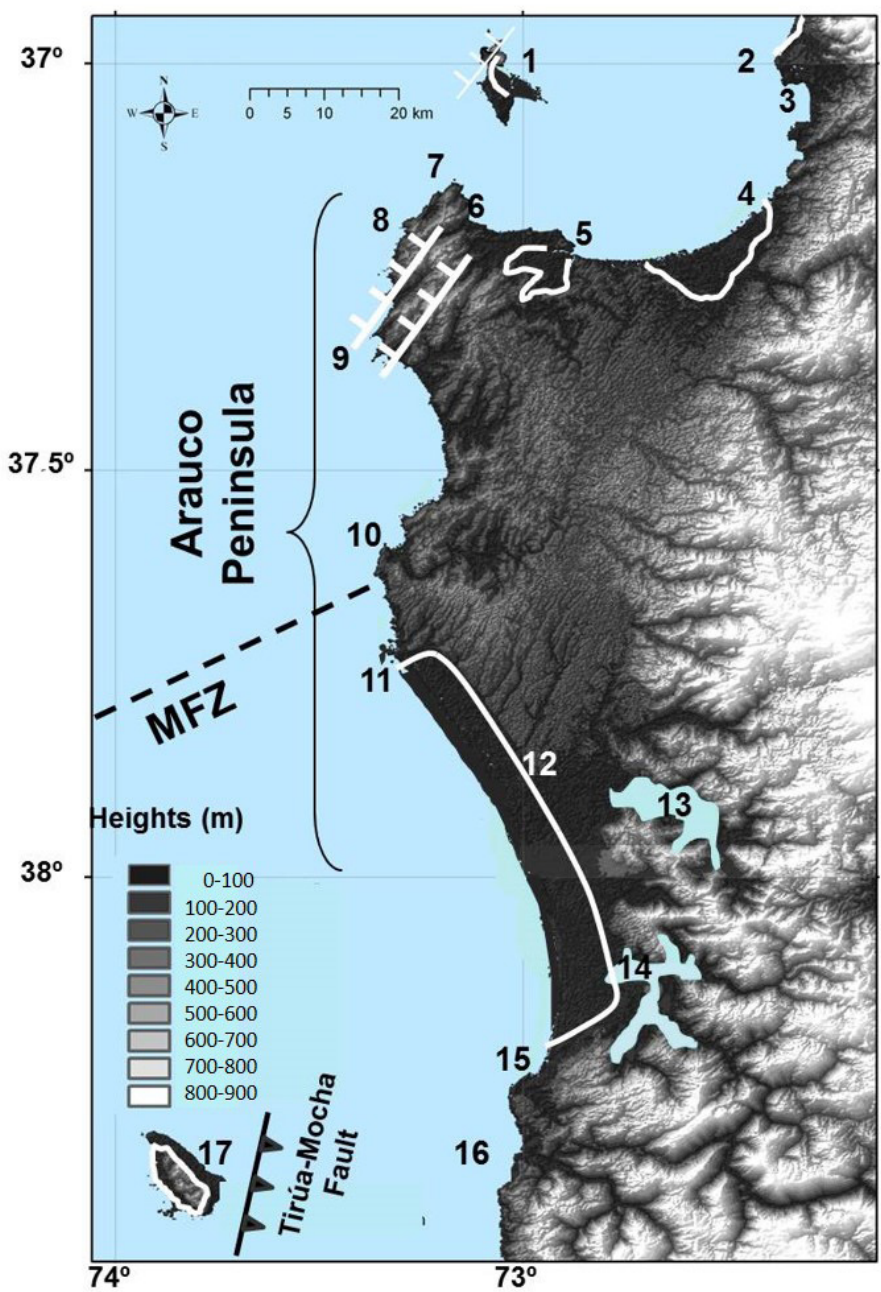

1 Santa Maria Island

2 Coronel

3 Playa Blanca

4 Laraquete

5 Tubul

6 Llico

7 Punta Lavapiè

8 Caleta Piures

9 Caleta Yani

10 Lebu

11 Punta Morhuilla

12 Pangue

13 Lanalhue Lake

14 Lleu Leu Lake

15 Quidico

16 Tirua

17 Mocha Island

FIG. 3. Morphologic and tectonic features of Arauco Peninsula, Santa María Island and Mocha Island. Normal faults at Arauco Peninsula and Santa María Island and Tirúa-Mocha splay fault are indicated. White line: border between Holocene and Pleistocene terraces (shorelineangle). Places mentioned in this paper are shown. MFZ: Mocha Fracture Zone trace. 


\section{Results}

\subsection{Pre Maule 2010 earthquake fieldwork}

Fieldwork was carried out between 2007 and 2009 in the coast of Biobío Region of Chile $\left(36.8^{\circ} \mathrm{S}-\right.$ $38.4^{\circ} \mathrm{S}$ ) including the Santa María Island, Mocha Island and Arauco Peninsula (Fig. 3). The Holocene shoreline angles (angle between the cliff and flat surface in an uplifted marine terrace) measured with differential GPS are: $9.5 \mathrm{~m}$ a.s.l. at Pangue $\left(37.84^{\circ} \mathrm{S}\right)$; $8.3 \mathrm{~m}$ a.s.l. at Santa María Island ( $\left.37^{\circ} \mathrm{S}\right)$, and $4 \mathrm{~m}$ a.s.l. in the continental margin in the eastern coast of Arauco Gulf at $37^{\circ} \mathrm{S}-37.2^{\circ} \mathrm{S}$ (Fig. 3). At Mocha Island we corroborated the $33 \mathrm{~m}$ a.s.l. of the shoreline angle of the highest Holocene terrace located at the northern border of Mocha Island at Cerro Los Chinos, and we observed the layer of mollusk shells that Nelson and Manley (1992) dated in 6,100-5,480 years (calibrated age).

Lebu underwent a coseismic ground uplift of 1.2-1.3 m during the Valdivia 1960 earthquake (Veyl, 1960; Saint Amand, 1961; Plafker and Savage, 1970). As a result Lebu river mouth dried out and the marine abrasion platform emerged (Figs. 4 and 5). This 1960 surface uplift was reversed in the 50 years between Valdivia 1960 and Maule 2010 earthquakes, so the marine platform became submerged and Lebu river mouth was navigable again (Fig. 5). The relative increase in sea level occurred during the interseismic 1960-2010 interval, in Santa María Island and the western border of Arauco Peninsula, caused several morphologic changes with consequences in the anthropic activity (Quezada et al., 2012, Figs. 4 and 5). The coastal cliff became active and the beaches narrower. In Tubul, Llico and Punta Lavapié (NW tip of Arauco Peninsula, (Fig. 3), the sea level increase generated that houses closer to the coast line were threatened, especially during winter storms, having forced the construction of a breakwater (Fig. 4). In Lebu, Punta Lavapié, Tubul and Llico the navigation was facilitated. 1960 coseismic ground uplift occurred also in Caleta Yani (37.36 ${ }^{\circ}$, Fig. 3): $0.7 \mathrm{~m}$ (Veyl, 1960) that also was recovered before 2010 Maule earthquake. On the contrary, the 1.5$1.8 \mathrm{~m}$ coseismic uplift in Mocha Island during the 1960 earthquake that produced the emersion of the marine abrasion platform, making possible the construction of a way that encircled the island, remained until the occurrence of Maule 2010 earthquake, as we could corroborate during our first trip to Mocha Island on November 6-7 2009 (Fig. 6). Before the 1960 earthquake, a dock was planned to build in Mocha Island. The construction began after this quake and was not considered in the original topographic map built before the 1960 earthquake, the coseismic uplift that generated a sea level drop, so once the dock was ended, it became useless. We saw this dock in November $6^{\text {th }} 2009$ remaining dry.

\subsection{Post Maule 2010 earthquake fieldwork}

Fieldwork was carried out during the three following months after the occurrence of Maule 2010 earthquake to determine the vertical coseismic ground movements in the rupture area from Valparaíso $\left(33^{\circ} \mathrm{S}\right)$ to Mocha Island $\left(38.6^{\circ} \mathrm{S}\right)$ (Fig. 1). This was done mainly along the coast where changes of the sea level related to vertical coseismic ground movements were observed (Fig. 3). Measurements were done considering the thickness of dead intertidal biota in channels of the rocks on normal waves surfaces avoiding splash effects in frontal waves surfaces that increased the thickness. Also vertical changes of the water level of river mouths and lakes were observed. In addition, an aerial reconnaissance was conducted over Santa María Island, Mocha Island and the western coast of the Arauco Peninsula to get an overview of the changes experienced along the coastal sectors. The coseismic uplift shown in figure 2 was determined at different places along the coastline between $33^{\circ} \mathrm{S}-38.6^{\circ} \mathrm{S}$ (Fig. 1) (Quezada et al., 2010, 2012). The amount of coesismic uplift decreases from trench to arc (from $\mathrm{W}$ to $\mathrm{E}$ ) being the largest coseismic uplift 2-2.5 $\mathrm{m}$ in Santa María Island and the western edge of Arauco Peninsula, places located closer to the trench (Fig. 2). Coseismic uplift produced the emersion of the marine abrassion platform, and the cliff become inactive and the intertidal biota died. The last is mainly represented by bleached Litothamnium. Beaches were widened, the Tubul-Raqui wetland became almost dry and Tirúa, Lebu and Tubul river mouths became almost dry (Figs. 4 and 7a). Lanalhue and Lleu Lleu lakes (37.9 ${ }^{\circ}$ S-38.2 ${ }^{\circ}$ S, Fig. 3) experienced an apparent eastward water flow with an increase of the water level in their east border and drops in the western one. The best-known effect is the flood of a dock located in the northeastern border of the Lleulleu Lake (Quezada et al., 2010, 2012). This effect could 

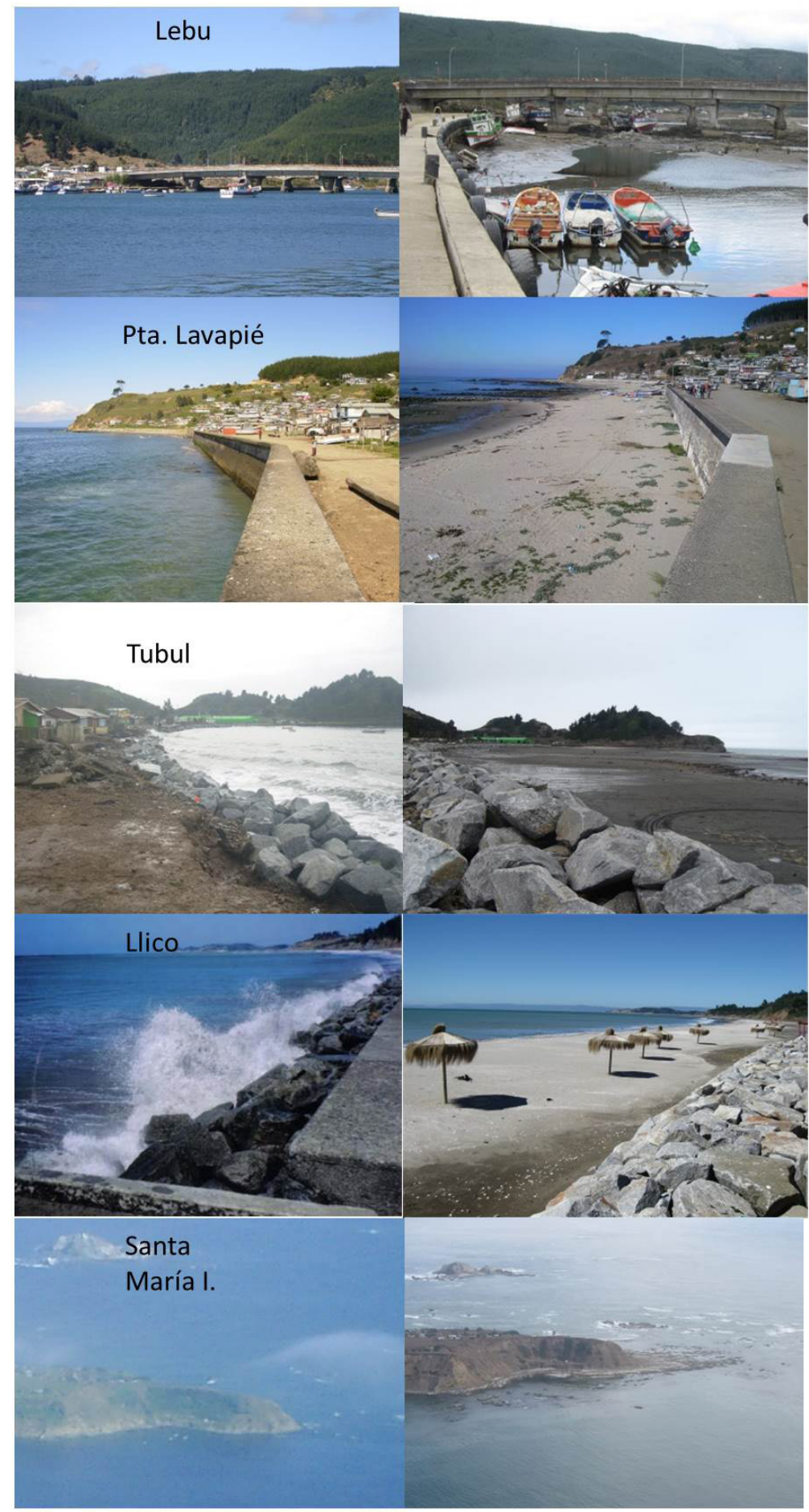

FIG. 4. Evidences of interseismic subsidence between Valdivia 1960 and Maule 2010 earthquakes (left) and 2010 coseismic uplift (right). Note the breakwater at Tubul, Llico and Punta Lavapié built due to threatening sea water because interseismic subsidence. Between Valdivia 1960 and Maule 2010 earthquakes, Lebu river became navigable and the coastal cliff at Santa María island active. After Maule 2010 earthquake, the sea withdrawal due to coseismic uplift provoked inactive cliff, dry Lebu river mouth as in 1960, emersion of marine abrasion platform and widening of the beaches (right). 


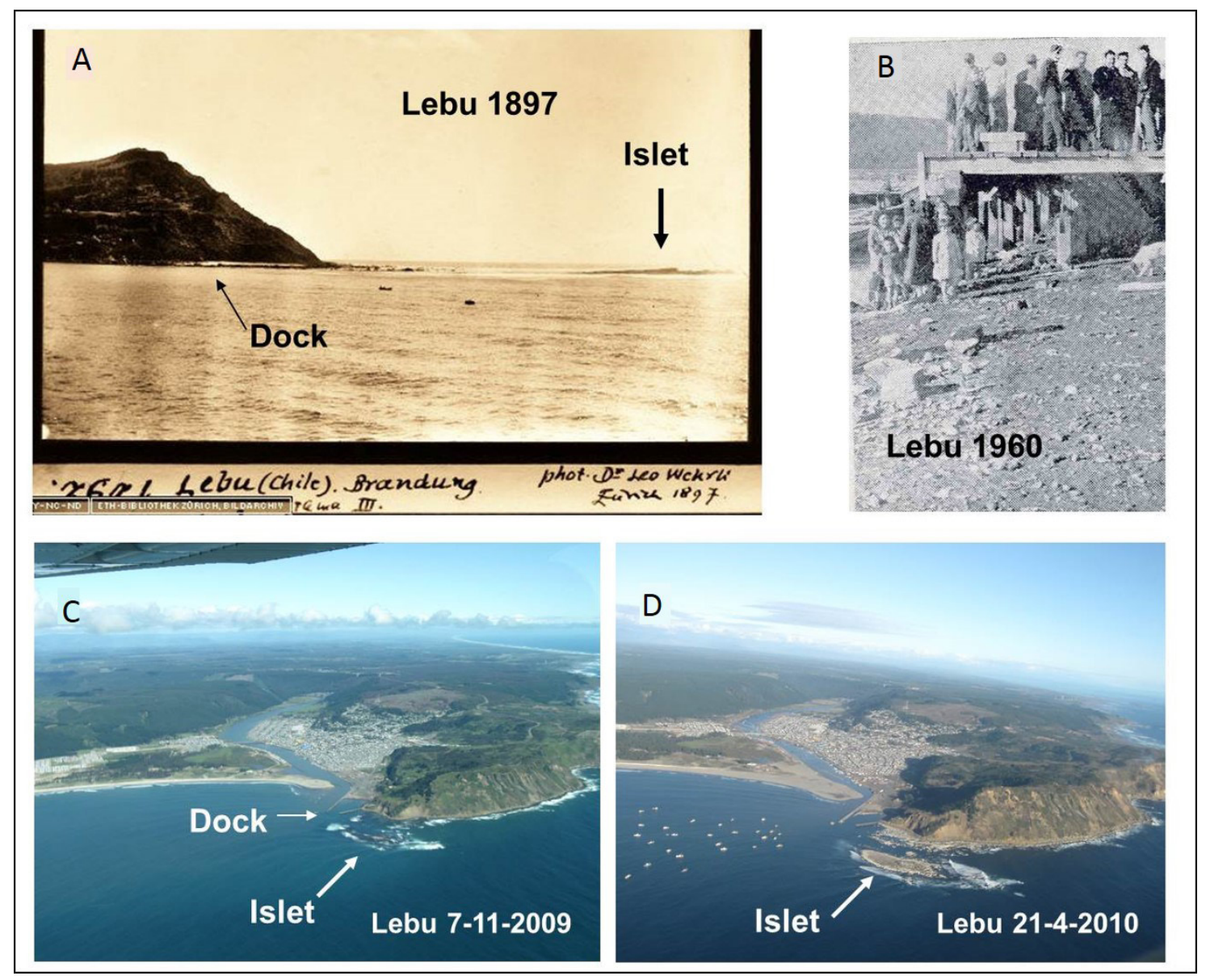

FIG. 5. Lebu at different years. A. 1897 picture showing the active cliff and small islet. B. 1960 coseismic uplift resulted in the dry dock (from Veyl, 1960). C. November $7^{\text {th }} 2009$ picture showing an active cliff and small islet. D. 2010 after Maule earthquake picture showing evidences of an emersion like big islet, inactive cliff and almost dry Lebu river mouth. Note the ships outside Lebu river mouth that cannot penetrate the river.

be the result of the eastward land tilting following the theoretically expected coseismic uplift pattern.

An unexpected Maule 2010 earthquake coseismic ground uplift trend occurred in the Tirúa-Mocha Island area $\left(38.2^{\circ} \mathrm{S}-38.4^{\circ} \mathrm{S}\right)$. Mocha Island, located $82 \mathrm{~km}$ east of the trench and in front of the continental coast at Tirúa was uplifted $0.25 \mathrm{~m}$, whereas Tirúa located $114 \mathrm{~km}$ from the trench, was uplifted $0.9 \mathrm{~m}$ (Fig. 2). The coseismic uplift in Tirúa was determined in the base of the bridge column by measuring the thickness of dead marine algae (Fig. 7B). The Tirúa river mouth became less navigable due to the diminishing water depth. Melnick et al. (2012) indicated $0.91 \mathrm{~m}$ of coseismic uplift at Tirúa, evidenced by dead intertidal biota in the coastal area as can be noted in figure 7C. Evidence of the coseismic uplift in Mocha Island is the sea level drop noted in a wall closer to the new dock in the eastern coast (Fig. 7D). The magnitude of the coseismic uplift determined by us in Mocha Island was $0.25 \mathrm{~m}$, similar to that indicated by Castilla et al. (2010), Farías et al. (2010), Vargas et al. (2011) and Melnick et al. (2012). Also big boulders are deposited by the tsunami (Fig. 8). In Quidico $\left(38.2^{\circ} \mathrm{S}\right)$ located at $118 \mathrm{~km}$ to the trench and $10 \mathrm{~km}$ north Tirúa, the coseismic uplift was also $90 \mathrm{~cm}$, measure based on the dead intertidal biota and the sea level fall observed in a protection wall. Whereas on a rock located in the beach $2.2 \mathrm{~km}$ north Quidico town, the thickness of dead biota is only $30 \mathrm{~cm}$. 


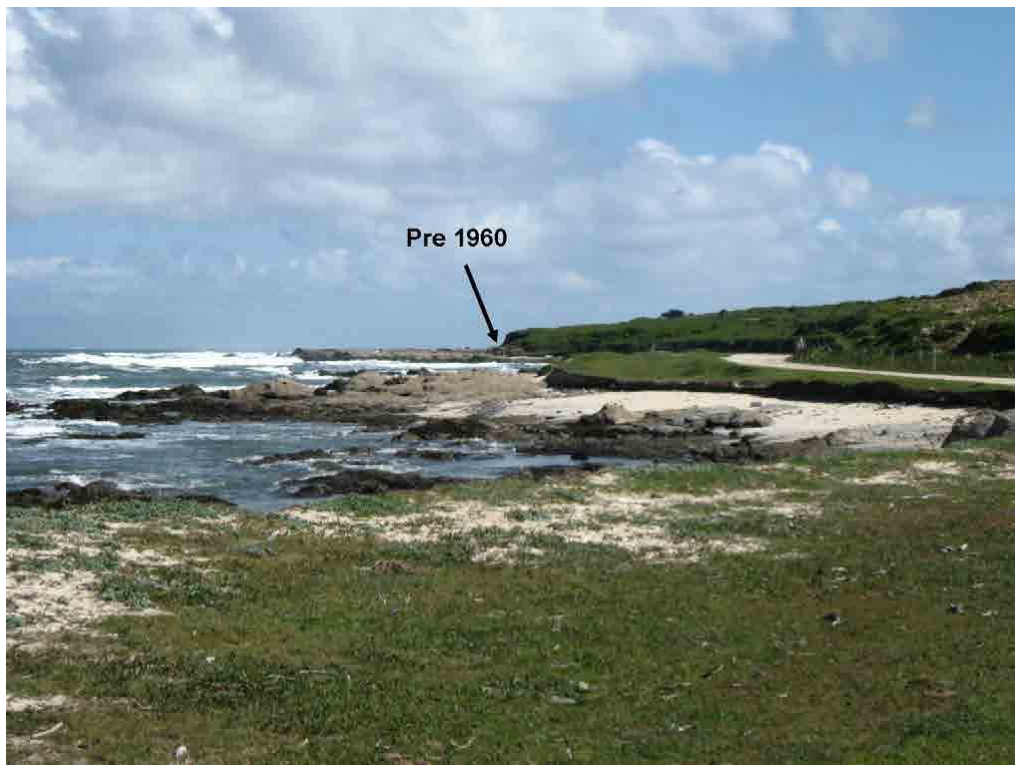

FIG. 6. Evidence of the permanence of the 1960 coseismic uplift at Mocha Island. The former position of the sea before Valdivia 1960 earthquake is displayed. The emersion of the marine abrasion platform allowed building a road that surround Mocha Island. Photo taken on November $6^{\text {th }} 2009$.

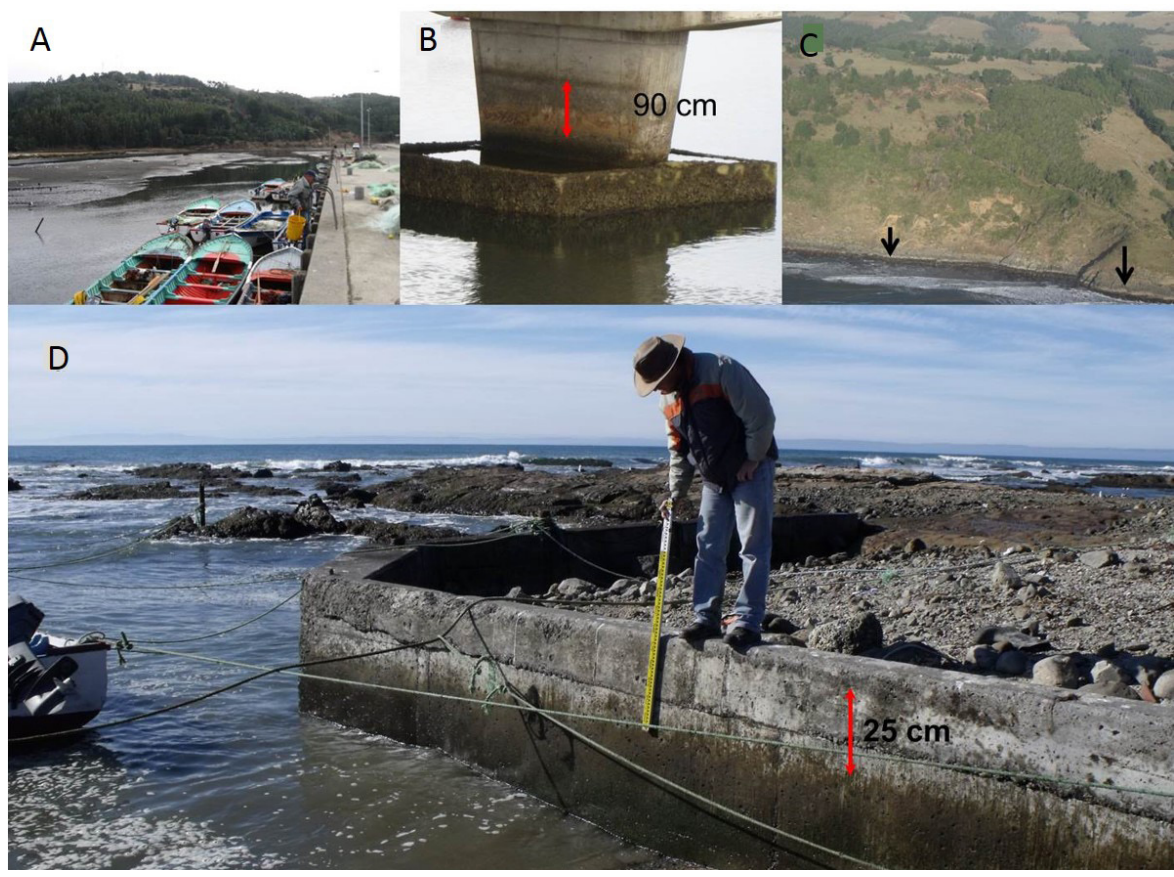

FIG. 7. Evidences of 2010 coseismic uplift at Tirúa (A,B,C) and Mocha island (D). A-B. Shows less water depth of Tirúa river and different level water marker at the base of the Tirúa brigde column, photo taken on April $27^{\text {th }} 2010$. C. Cliff arriving at Tirúa from Mocha Island on May $27^{\text {th }}$ 2010. The black arrows indicates the top of the bleached Lithotamnium. D. Sea level drop of $25 \mathrm{~cm}$ at the eastern coast of Mocha Island. The former sea level is visible in a dark line that begins in a point close to the shoes of the guy that extends to the right. The dark zone on the bottom of the wall is living marine algae and the top level is the position of the new high tide. A white zone between both levels is bleached dead algae equivalent to the 2010 coseismic uplift. Photo taken on May $27^{\text {th }} 2010$. 


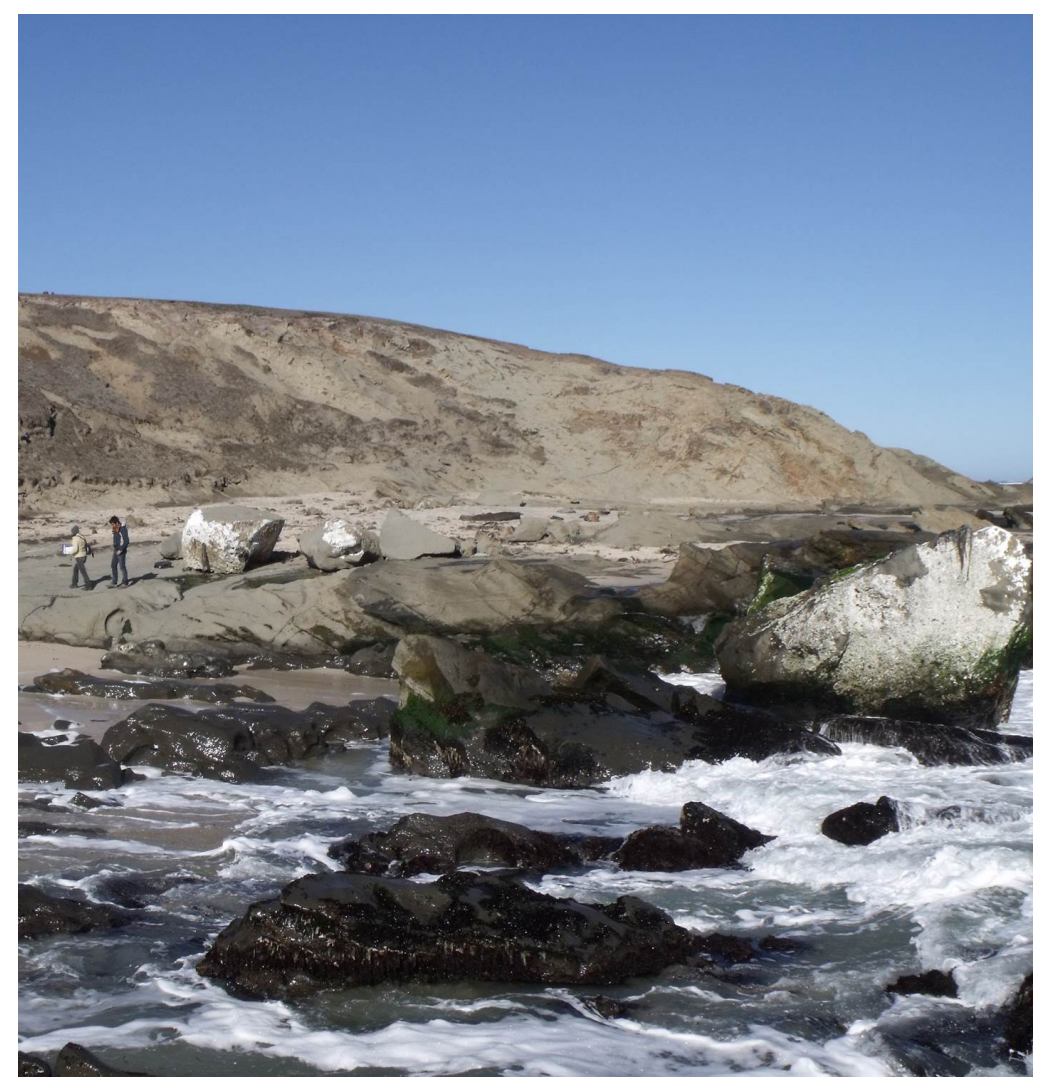

FIG. 8. Big sandstone boulders moved by the 2010 tsunami at the northern border of Mocha Island. The white colour is bleached Lithotamnium. The tsunami overwashed the entire slope behind the picture and the water continued its way at least $200 \mathrm{~m}$ inner plain depositing more boulders and reach the 20 m runup.

\subsection{Post January $2^{\text {nd }} 2011 \mathrm{Mw}=7.1$ Araucanía earthquake fieldwork}

A strong $\mathrm{Mw}=7.1$ aftershock, with epicentre in the Tirúa-Mocha Island area, occurred on January $2^{\text {nd }} 2011$ (Araucanía 2011 earthquake) showing a reverse focal mechanism (Moreno et al., 2011; Kiser and Ishii, 2013, Fig. 1). This event was one of greatest aftershocks of Maule 2010 earthquake. National Earthquake Information Center (NEIC) located this event at $38.35^{\circ} \mathrm{S} / 73.27^{\circ} \mathrm{W}(13 \mathrm{~km}$ from the southern coast of Lleulleu Lake) and $25.1 \mathrm{~km}$ depth, thrust focal mechanism with rupture plane $\mathrm{N} 4^{\circ} \mathrm{E} / 16^{\circ} \mathrm{E}$ corresponding to Wadati-Benioff. The Centro Sismológico Nacional (National Seismological Centre of Chile, of Universidad de Chile, CSN), located this event at $38.36^{\circ} \mathrm{S} / 75.03^{\circ} \mathrm{W}(15 \mathrm{~km}$ west of the trench axis at Mocha Island latitude) and at $32.1 \mathrm{~km}$ depth (Fig 1). The Araucanía 2011 earthquake was relocated by CSN on September 2012. The new coordinates for the epicentre are $38.343^{\circ} \mathrm{S} / 73.961^{\circ} \mathrm{W}$ and de new depth was $17.8 \mathrm{~km}$. This location coincides with the NW tip of Mocha Island, $87 \mathrm{~km}$ east to the trench axis. Hicks and Rietbrock (2015) studied in detail this earthquake concluding that this event is composed of two ruptures on two separate faults. Within $12 \mathrm{~s}$ a thrust earthquake on the plate interface triggered a second large rupture on a normal fault $30 \mathrm{~km}$ away in the overriding plate. Two locations of the epicentre they displayed: $38.47^{\circ} \mathrm{S} / 73.82^{\circ} \mathrm{W}$ at $39 \mathrm{~km}$ depth and $38.54^{\circ} \mathrm{S} / 73.73^{\circ} \mathrm{W}$ at $23 \mathrm{~km}$ depth (both locations lies between Tirúa and Mocha Island). Also the epicentre of this event is displayed by the GFZ-GEOFON: $38.23^{\circ} \mathrm{S} / 72.33^{\circ} \mathrm{W}$ at $12 \mathrm{~km}$ depth (This location lies in the coast zone near Quidico).

A new land recognition in the area of Tirúa-Mocha Island was conducted to determine possible vertical coseismic ground movements after the Araucanía 
2011 earthquake. Such fieldwork was carried out on January $20^{\text {th }} 2011$ in the places of Quidico, Tirúa and Mocha Island that had been visited previously. We could document a new uplift of $50 \mathrm{~cm}$ in Mocha Island and a subsidence of $20 \mathrm{~cm}$ in Tirúa. Evidence of this uplift in Mocha Island is the new emersion of the marine abrasion platform. Measurements in the same place that was visited on May $27^{\text {th }} 2010$ $\left(38.33^{\circ} \mathrm{S} / 73.91^{\circ} \mathrm{W}\right)$, indicated a relative sea level drop of $50 \mathrm{~cm}$ (Fig. 9A,B). In another point, at Las Ballenas $\left(38.35^{\circ} \mathrm{S} / 73.90^{\circ} \mathrm{W}\right)$, in a vertical rocky wall protected from the sea waves, a recently bleached Litothamnium layer, with a thickness of $50 \mathrm{~cm}$, is visible and can be separated of a remnant of a $20-30 \mathrm{~cm}$ former bleached Litothamnium layer generated after Maule 2010 earthquake. In that locality, also dead marine algae such as Ulva lactuca and other species were observed in coastal rocks as occurred after Maule earthquake along the shore of Biobío Region of Chile $\left(36,5^{\circ} \mathrm{S}-38,4^{\circ} \mathrm{S}\right)$. The total surface uplift of the Mocha Island after Maule 2010 earthquake and Araucanía 2011 earthquake is of $75 \mathrm{~cm}$. In Tirúa, the river mouth showed a significant increase in water depth and navigation was again possible. When comparing the position of the water level in the base of the columns of the Tirúa Bridge, it could be established an increase of the level of waters corresponding to a coseismic subsidence of $20 \mathrm{~cm}$ (Fig. 9C and D). These variations were observed during low tide. January is the dry season in south Chile, when rivers are in their base flow. The oscillation between low and high tide is one
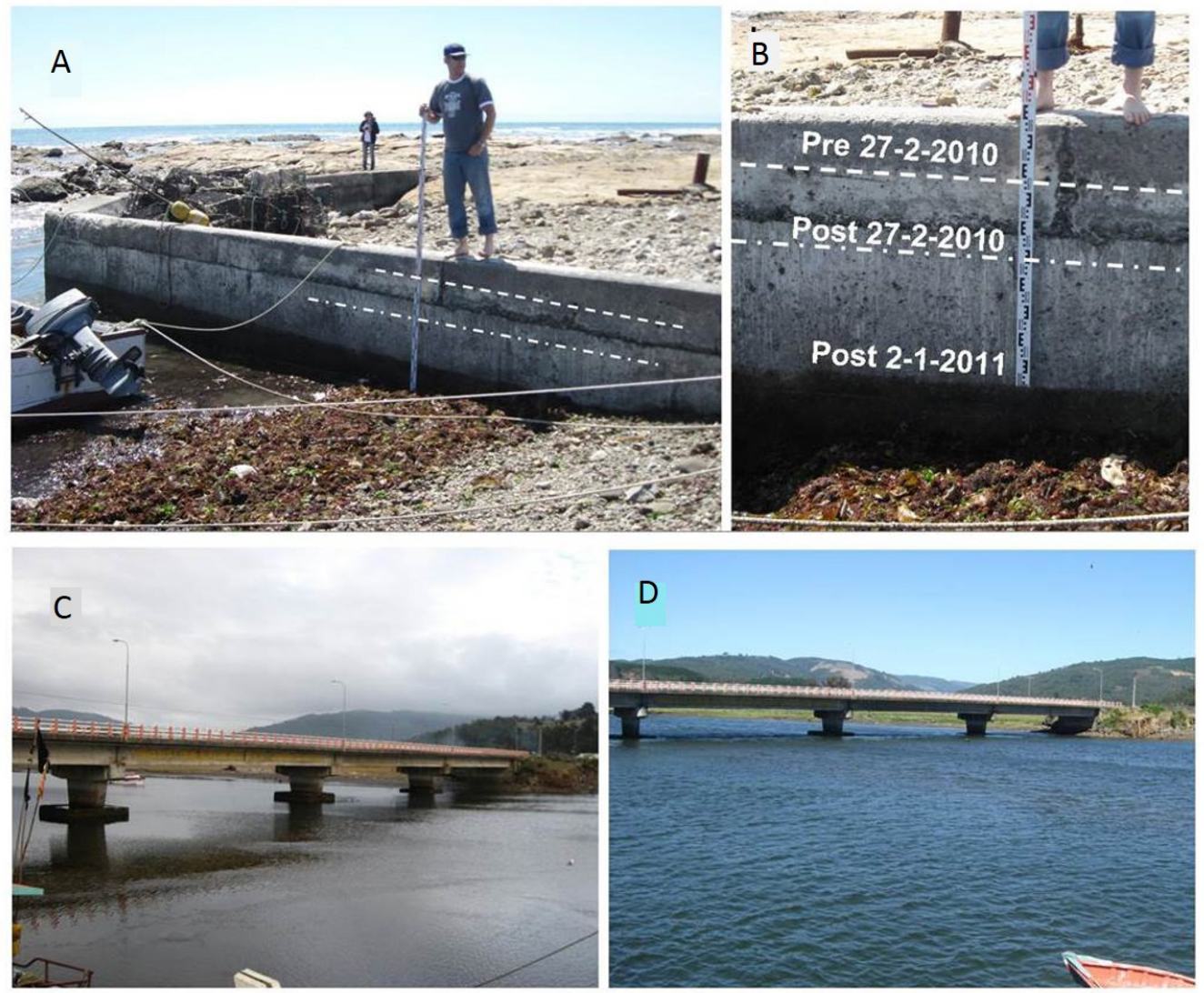

FIG. 9. Evidences of vertical changes at Mocha Island and Tirúa after Araucanía 2011 earthquake. A-B. Same place at Mocha Island shown in figure 7D. It is clear the sea level drop of $50 \mathrm{~cm}$. C-D. Tirúa bridge. Left photo taken on April $27^{\text {th }} 2010$ one hour after the low tide. Right photo: same view on January $20^{\text {th }} 2011$ at the time of low tide. Note the upper position of the water in the columns evidenced $20 \mathrm{~cm}$ of subsidence after the $\mathrm{Mw}=7.1$ event. The Tirúa River had more caudal on January 2011, even if we consider that this is the summer dry season. 
meter with insignificant variations during a year, as reported by the Servicio Hidrográfico y Oceanográfico de la Armada, SHOA (Chilean Hydrographic and Oceanographic Service). At Quidico vertical variations were not detected when comparing observations in littoral rocks on April $27^{\text {th }} 2010$ and January $20^{\text {th }}$ 2011. The Araucanía earthquake generated a small tsunami that penetrated the Tirúa river without any damages and was not sensible in Mocha Island. The upstream flow along Tirúa River could be another indicator of the Tirúa subsidence due to the change of Tirúa River base level.

\section{Elastic dislocation models}

To account for the vertical movements linked with the Valdivia 1960 and Maule 2010 earthquakes, the interseismic period between both earthquakes and the January $2^{\text {nd }}$ Araucanía 2011 aftershock, we used a software developed from the Okada (1992) equations that computes the internal displacement $u$ $(\mathrm{x}, \mathrm{y}, \mathrm{z})$ due to shear faults in an elastic half-space given a rectangular fault geometry (length, width, depth, dip) and 2-component dislocation amplitude (rake and slip) and followed the methodology used by Farías et al. (2010) and Chapman et al. (2014) to model vertical changes for $\mathrm{Mw}=8.8$ Maule 2010 earthquake and $\mathrm{Mw}=9.2$ Alaska 1964 earthquake respectively, obtaining plate slip, depth, dip and rake. Lamé's constants $\lambda$ and $\mu$ for a material in an elastic half-space are considered equals. For each model are considered the vertical movements during specific seismic events or interseismic period, and fault parameters: rake, slip, dip and depth. The trench parallel length of each model was $450 \mathrm{~km}$, only done to avoid lateral border effects. The width of Wadati-Benioff and splay fault planes are displayed in figure 10. It is assumed that the maximum and minimum depth defines the position of the seismic asperity in the fault plane or zone of fault dislocation. The vertical movements at each place with determined coseismic and interseismic uplift with corresponding normal trench distance, must be fitted with a specific fault geometry, location and slip. The rake considered in the coseismic models was $90^{\circ}$ considering only dip slip and for the interseismic models B and C, was used a rake of $-90^{\circ}$. After iteration, the best fit is shown in each case (Fig. 10). Some models consider as fault the Wadati-Benioff plane and others a splay fault located between Tirúa and Mocha Island with same vergence but steeper dip than that of the WadatiBenioff plane. This is the same methodology used by Chapman et al. (2014) to explain the activity of the Suckling Hills splay fault during the Alaska 1964 earthquake. Each place has determined coseismic or interseismic uplift with corresponding normal trench distance and the black line is the fault modeled and the dashed line the other fault not considered in each model. As explained before, the uncertainties of each data is $\pm 10 \mathrm{~cm}$ so only the mean value is displayed. A number of studies have analyzed and modeled the seismotectonic framework of the Maule 2010 earthquake rupture zone (e.g., Hayes et al., 2013 and references there in). These studies indicate that the dip of the Wadati-Benioff plane ranged from 15 to $18^{\circ}$. However, considering the focal solutions of the 2010 and 2011 events, a better solution for the Wadati-Benioff geometry is the dip of the nodal plane for the Tirúa-Mocha Island area.

Model A corresponds to the 1960 earthquake at Tirúa and Mocha Island area. The dip came from the NEIC focal mechanism of Araucanía 2011 earthquake: $16^{\circ}$ corresponding to the Wadati-Benioff plane at that zone and rake $90^{\circ}$. Two places were considered to fit the vertical coseismic movements: Mocha Island and Tirúa with normal trench distances of 82 and $114 \mathrm{~km}$ respectively. The coseismic uplift of both places during 1960 earthquake was $c a .1 .5 \mathrm{~m}$ at Mocha Island and $-0.2 \mathrm{~m}$ at Tirúa (Plafker and Savage, 1970). The best fit was reached by using a depth asperity between 10 and $40 \mathrm{~km}$, and $8 \mathrm{~m}$ slip. Another model with $10 \mathrm{~m}$ slip does not fit very well (Fig. 10A). Root mean square error (RMS) for $8 \mathrm{~m}$ slip $=0.3019$ and with $10 \mathrm{~m}=0.4441$. Model B corresponds to the interseismic period between Valdivia 1960 and Maule 2010 earthquakes in four places located around $37.1^{\circ} \mathrm{S}$ (coincides with the northern border of Arauco Peninsula): Santa María Island, Llico, Santa Juana and Laja with normal trench distances of $90,100,160$ and $180 \mathrm{~km}$ respectively. The interseismic vertical movement used came from the ratios obtained by GPS measures in $\mathrm{mm} /$ year from Moreno et al. (2011): Santa María Island: -8.85, Llico: -4.81, Santa Juana: 5.48, and Laja: 3.5. If we multiply such ratios of the interseismic vertical movements by 50 , we can obtain the total interseismic movement during 50 years. By doing this, we obtained $-0.44 \mathrm{~m}$ at Santa María Island, $-0.24 \mathrm{~m}$ at Llico, $0.278 \mathrm{~m}$ at Santa Juana and $0.18 \mathrm{~m}$ at Laja. We consider the Wadati-Benioff plane with $19^{\circ}$ dip corresponding 


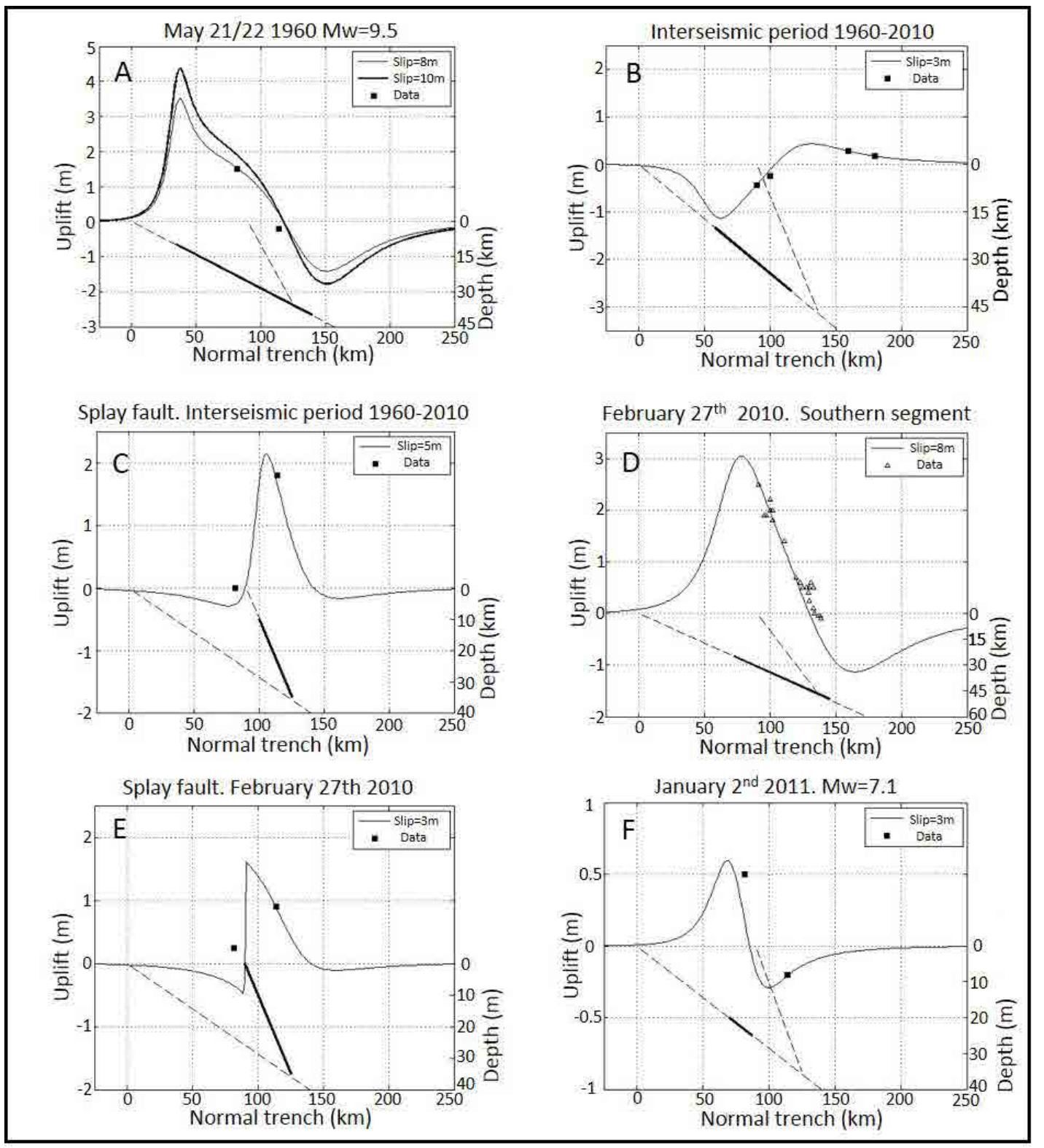

FIG. 10. Elastic dislocation models of vertical coseismic and interseismic movements considering the Wadati-Benioff plane and the Tirúa-Mocha Splay fault (with bigger dip). In each case the fault modelled is displayed as a thick solid line. A. Coseismic uplift/subsidence Valdivia 1960 earthquake at Tirúa and Mocha Island area, movement only along Wadati-Benioff. B. Interseismic period 1960-2010 at 37.1 $\mathrm{S}$; movement only along Wadati-Benioff. C. Interseismic period 1960-2010 at TirúaMocha Island area considering activity of Tirúa-Mocha Splay fault. D. 2010 coseismic uplift/subsidence Maule earthquake at southern segment $\left(36^{\circ} \mathrm{S}-38.1^{\circ} \mathrm{S}\right)$; movement only along Wadati-Benioff. E. 2010 coseismic uplift Maule earthquake at Tirúa-Mocha Island area with activity of the Tirúa-Mocha Splay fault. F. Coseismic Mw=7.1 event of January $2^{\text {nd }} 2011$ considering movement at updip of Wadati-Benioff plane.

to the focal mechanism of Maule 2010 earthquake and rake $-90^{\circ}$. The best model fit is obtained with a depth asperity of 20-40 km and $3 \mathrm{~m}$ of fault slip.
$\mathrm{RMS}=0,0626$. Model $\mathrm{C}$ corresponds to the splay fault activity during the interseismic period between Valdivia 1960 and Maule 2010 earthquakes at Tirúa 
and Mocha Island. For Mocha Island we considered $0 \mathrm{~m}$ vertical movement considering our observations before Maule earthquake (Fig. 6) indicating vertical stability between Valdivia 1960 and Maule 2010 earthquakes.

For Tirúa as in model B, we multiplied the GPS measurement from Moreno et al. (2011): $36.86 \mathrm{~mm} / \mathrm{y}$ by 50 years obtaining $1.8 \mathrm{~m}$ interseismic uplift. This is an unexpected interseismic uplift trend considering that Mocha Island must have interseismic subsidence (place close to the trench like Lebu or Santa María Island) and Tirúa a moderate interseismic uplift (place close to the transition zone between uplift and subsidence). For this reason, a splay fault is assumed between Tirúa and Mocha Island trying to explain this situation. The best model obtained was considering a splay fault of $45^{\circ}$ dip and $5 \mathrm{~m}$ slip. The position of the splay fault is determined considering that the tip point is located between Tirúa and Mocha Island at $90 \mathrm{~km}$ from the trench and the splay fault branches from Wadati-Benioff plane at $35 \mathrm{~km}$ depth that corresponds to one of Wadati-Benioff plane in the area between Tirúa and Mocha Island. The depth of the splay fault is fitted between 10 and $35 \mathrm{~km}$. $\mathrm{RMS}=0.2100$.

Model D corresponds to the coseismic movement at the southern segment of Maule 2010 earthquake between Cobquecura and the southern border of Arauco Peninsula $\left(36^{\circ} \mathrm{S}-37.7^{\circ} \mathrm{S}\right)$. Considering the existence of Arauco, Hualpén and Tumbes peninsulas, Quiriquina Island and Santa María Island (coastal places located between $36.8^{\circ} \mathrm{S}-37.7^{\circ} \mathrm{S}$ ), there are many points at different normal trench distances with differential vertical coseismic uplift. We used our measurements indicated in Quezada et al. $(2010,2012)$. It was considered $19^{\circ}$ dip for the Wadati-Benioff plane corresponding to the NEIC focal mechanism of Maule earthquake. The best fit was with $8 \mathrm{~m}$ slip along the Wadati-Benioff plane with asperity position between 25 and $50 \mathrm{~km}$. $\mathrm{RMS}=0.3221$. Model $\mathrm{E}$ corresponds to a splay fault activity during Maule 2010 earthquake at Tirúa and Mocha Island. We considered the coseismic uplift of $0.9 \mathrm{~m}$ at Tirúa from Melnick et al. (2012) and our own data of $0.25 \mathrm{~m}$ at Mocha Island, using the same geometry of the splay fault of model $\mathrm{C}$ but with depth rupture between 0 and $35 \mathrm{~km}$ i.e., the rupture of the splay fault reached the sea bottom. The best fit was considering a splay fault slip of $3 \mathrm{~m}$. $\mathrm{RMS}=0.4336$. Model $\mathrm{F}$ corresponds to the $\mathrm{Mw}=7.1$
January $2^{\text {nd }}$ Araucanía 2011 earthquake considering movement only in the Wadati-Benioff plane. The dip is $16^{\circ}$ from NEIC focal mechanism of such event. The coseismic uplift from our fieldwork is $-0.2 \mathrm{~m}$ at Tirúa and $0.5 \mathrm{~m}$ at Mocha Island. The best fit is obtained with depth rupture between $20-25 \mathrm{~km}$ and slip $3 \mathrm{~m}$, with a RMS $=0.2387$. It is worth noting that the CSN epicentre lies in the vertical projection of such segment of Wadati-Benioff plane.

\section{Discussion}

\subsection{Coseismic and interseismic ground surface uplift at Tirúa-Mocha Island area}

The zone of Tirúa-Mocha Island had a different seismic behaviour than theoretically expected (Fig. 2). During the $\mathrm{Mw}=9.5$ Valdivia 1960 earthquake, typical coseismic vertical movements occurred where Mocha Island experienced uplift and Tirúa subsidence. It means that the coseismic slip occurred only in the Wadati-Benioff plane as shown in Model A with $8 \pm 0.3 \mathrm{~m}$ slip (Fig. 10A). Several researches for the 1960 earthquake (Plafker and Savage, 1970; Plafker, 1972; Cifuentes, 1989; Barrientos and Ward, 1990; Tichelaar and Ruff, 1991) also indicated that the main slip occurred only along Wadati-Benioff plane and not in any splay fault.

However, during the interseismic period between Valdivia 1960 and Maule 2010 earthquakes, an unexpected behaviour occurred, the 1960 coseismic uplift at Mocha Island remained, or even should be increased (Nelson and Manley, 1992) and the theoretically expected interseismic subsidence did not occur. This contrast with the normal interseismic subsidence observed at other near trench islands such as Santa María Island after the Concepción 1835 earthquake (Wesson et al., 2015) and Guafo Island $\left(43.6^{\circ} \mathrm{S}\right)$ after the Valdivia 1960 earthquake (Melnick et al., 2018); and also in the western border of Arauco Peninsula and Santa María Island (Fig. 4).

The amount of interseismic uplift at Mocha Island after Valdivia 1960 earthquake indicated by Nelson and Manley (1992) was $70 \mathrm{~mm} / \mathrm{y}$ between 1965 and 1989 measuring tidal changes. This means a net uplift of $1.68 \mathrm{~m}$. By the other hand, GPS data in the previous decade of Maule earthquake (Moreno et al., 2011), indicates a very small subsidence in Mocha Island: $1.07 \mathrm{~mm} / \mathrm{y}$. This means a net subsidence of $0.01 \mathrm{~m}$ in 10 years or $0.05 \mathrm{~m}$ in 50 years. If we 
considered the Nelson and Manley (1992) uplift data at Mocha island, the addition of the $1.5 \mathrm{~m} 1960$ coseismic uplift and following interseismic $1.68 \mathrm{~m}$ uplift means a net uplift of $c a .3 \mathrm{~m}$. The following small subsidence (Moreno et al., 2011) must have not significant opposite effect of this uplift. However our observations (Fig. 6) indicates that the uplift of Mocha Island before Maule 2010 earthquake is not bigger that $1.5 \mathrm{~m}$. This coincides with the 1960 coseismic uplift. So many situations may have occurred. An over estimation of the following interseismic uplift at Mocha Island by Nelson and Manley (1992) that can include some of the 1960 coseismic uplift, a fast interseismic subsidence between 1989 and 2000; an underestimation of the interseismic subsidence before Maule earthquake (Moreno et al., 2011), or a vertical stability between 1960 and 2010 earthquakes. Based on our observations on the amount of emersion of the marine abrasion platform we favor the last option (Fig. 6) that is consistent with the very small amount of subsidence indicated by Moreno et al. (2011). In any case a 0 net uplift or subsidence occurred at Mocha Island between 1960 and 2010 earthquakes.

This contrasts with the normal interseismic subsidence observed at other near trench islands such as Santa María Island after the Concepción 1835 earthquake (Wesson et al., 2015) and Guafo Island $\left(43.6^{\circ} \mathrm{S}\right)$ after the Valdivia 1960 earthquake (Melnick et al., 2018); and also in the western border of Arauco Peninsula (Fig. 4). For example 20.08 mm/y subsidence was detected at Lebu (Figs. 4 and 5) before 2010 Maule earthquake (Moreno et al., 2011). Lebu also experienced 1.2-1.8 m uplift during the Valdivia 1960 earthquake (Veyl, 1960; Saint Amand, 1961; Plafker and Savage, 1970; Pizarro, 1991; Bustamante and Valenzuela, 2010). Lebu is located between Mocha Island and Santa María Island (Fig. 3), places uplifted during the Concepción 1835 earthquake (Fitz-Roy, 1839), so Lebu must be uplifted also during such earthquake. Pizarro (1991) indicated $2 \mathrm{~m}$ coseismic uplift at Lebu river mouth during the 1835 earthquake. The 1897 picture of Lebu (Fig. 5A), shows an active cliff and a small islet, similar features that we found before 2010 Maule earthquake (Figs. 4 and 5C), so Lebu must have been also experienced fast interseismic subsidence after 1835 earthquake. In contrast Tirúa, located to the south (Fig. 3) experienced a big interseismic uplift before Maule 2010 earthquake: $36.86 \mathrm{~mm} / \mathrm{y}$ while Quidico, had a subsidence of $2.26 \mathrm{~mm} / \mathrm{y}$ (Moreno et al., 2011). The amount of interseismic uplift at Tirúa, is the biggest of any place in the later rupture zone of Maule 2010 earthquake $\left(33^{\circ} \mathrm{S}-38.6^{\circ} \mathrm{S}\right)$, as can be shown in GPS data by Ruegg et al. (2009) and Moreno et al. (2011), being bigger even than places located inland such as Coastal Cordillera and Central Depression, zones where is expected theoretically an important interseismic uplift. As shown in model B (Fig. 10B), where occurred normal interseismic period in which both plates are coupled and the movement occurred only in the Wadati-Benioff plane, places located close to the trench had interseismic subsidence and distant places (eastward in Coastal Cordillera and Central Depression) had interseismic uplift. So movement only along Wadati-Benioff plane explains well the interseismic subsidence at Santa María Island and Arauco Peninsula after 1835 and 1960 earthquakes. The vertical net interseismic (1960-2010) stability at Mocha Island and high uplift at Tirúa are an unexpected interseismic behaviour, and could be explained by the activity of a splay fault as shown in model C (Fig. 10C). From this model, such a splay fault must be located between Tirúa and Mocha Island, whose trace is located at $90 \mathrm{~km}$ from trench, close to the eastern coast of Mocha Island with $45^{\circ}$ dip and branches west vergent from Wadati-Benioff plane at $35 \mathrm{~km}$ depth. The tip point of the fault is located at $10 \mathrm{~km}$ depth and the main slip (5 m) occurred between 10-35 km depth.

\subsection{Tirúa-Mocha splay fault}

During the Maule 2010 earthquake, theoretically expected coseismic vertical ground movements with decreasing vertical uplift from trench to the Andes Cordillera occurred in most of the rupture zone with the exception of Tirúa-Mocha Island area (Fig. 2). As shown in model D (Fig. 10D), the slip that occurred in Arauco Peninsula and northward including Santa María Island, can be explained by $8 \pm 0.3 \mathrm{~m}$ slip only in the Wadati-Benioff plane. In contrast, as shown in Model E (Fig. 10E), the smaller uplift in Mocha Island than Tirúa, can be explained by activity only in the splay fault with $3 \pm 0.4336 \mathrm{~m}$ slip that reached the sea bottom. This is similar to the situation that occurred during the 1964 Alaska earthquake were some splay faults were active such as the Hanning bay and Patton Bay splay faults that were visible in Montage Island (Plafker, 1972) generating additional vertical uplift, and the Suckling Hills splay fault that 
explains the abnormal high coseismic movement in the border of Alaskan and Aleutian subduction zones (Chapman et al., 2014) or several splay faults activated during the New Zealand 2016 Kaikoura Earthquake (Hollingsworth et al., 2017; Wang et al., 2018). Finally, the vertical ground movements at Tirúa-Mocha Island area during the Araucanía 2011 earthquake display a normal trend, with bigger uplift at Mocha Island and subsidence at Tirúa. From model F (Fig. 10F), that coseismic uplift trend, can be explained by activity only in the Wadati-Benioff plane at 20-25 km with $3 \mathrm{~m}$ slip.

The models that explain the coseismic movements during the Valdivia 1960, Maule 2010 and Araucanía 2011 earthquakes and the interseismic movements between 1960 and 2010 earthquakes (Fig. 10) indicates that in the Tirúa-Mocha Island area there is a splay fault (Tirúa-Mocha splay fault), whose trace must be located between Tirúa and Mocha Island near the eastern coast of Mocha Island. Considering the aftershocks distribution of the Araucanía 2011 earthquake (Hicks and Rietbrock, 2015) between $38.2^{\circ} \mathrm{S}-38.6^{\circ} \mathrm{S}$ (NEIC and CSN), and the changes in interseismic and coseismic (Maule 2010 earthquake) uplift trend: typical trend north of Quidico $\left(38.2^{\circ} \mathrm{S}\right)$ and unexpected to the south of this place (Fig. 2), the length of the Tirúa-Mocha splay fault extends at least between $38.2^{\circ} \mathrm{S}-38.6^{\circ} \mathrm{S}$, i.e., $40 \mathrm{~km}$. Their strike would be parallel to the trench: $\mathrm{N} 10^{\circ} \mathrm{E}$, dip bigger than the $19^{\circ}$ of the Wadati-Benioff plane, determining $45^{\circ}$ (Model C) and west vergent. Hicks and Rietbrock (2015) indicated that the crustal splay fault active during Araucanía 2011 earthquake is east vergent so, Mocha Island must have subsidence and Tirúa uplift, that is the opposite that occurred. So the true fault must be west vergent.

The distribution of the aftershocks of Maule 2010 earthquake is compatible with the existence of the Tirúa-Mocha splay fault. Relocated aftershocks of Maule 2010 earthquake, before Araucanía 2011 earthquake (Lange et al., 2012; Rietbrock et al., 2012; Hayes et al., 2013), suggest that such seismicity has a $\mathrm{N} 15^{\circ} \mathrm{E}$ trend, subparallel to the trench axis. Moreover, south from $38^{\circ} \mathrm{S}$ there is a narrower dispersion of the seismicity along the $\mathrm{N} 15^{\circ} \mathrm{E}$ axis including the Mocha Island. The distribution of epicentres along this axis concentrates between the continental shoreline and the Mocha Island, without a seismicity closer to the trench, unlike what happens northward such as Arauco Peninsula with aftershocks close to the trench. The distribution of the Maule 2010 earthquake aftershocks at Tirúa-Mocha area, coincides with the horizontal projection of the probable TirúaMocha splay fault plane suggesting its activation during Maule Earthquake and some months after, but before the Araucanía 2011 earthquake. Lange et al. (2012), Rietbrock et al. (2012) and Hayes et al. (2013) provide vertical profiles of the region, but they do not cover the Tirúa-Mocha area (south from $38^{\circ} \mathrm{S}$ ) fully, since their southernmost profiles are around $37.5^{\circ} \mathrm{S}$ and the vertical distribution of the hypocentres is scattered. As consequence of this scattered distribution, it is difficult to discern inter from intraplate events. The lack of aftershocks between Mocha Island and the trench may indicates a high coupled zone, for example the existence of a strong asperity at the updip of Wadati-Benioff plane at Tirúa-Mocha Island area.

Regarding the Araucanía 2011 earthquake, Hicks and Rietbtrock (2015) identifed two rupture planes, one on the Wadati-Benioff with thrust focal mechanism and the other on the overriding crust with normal focal mechanism. They divided the aftershocks of Araucanía 2011 earthquake in two clusters, one close to Tirúa with thrust focal mechanisms along the WadatiBenioff zone, and the other mainly to the south and close to the eastern coast of Mocha Island with normal focal mechanisms corresponding to the crustal fault. They concluded that this interplate event triggered the rupture of the crustal fault, suggesting that such fault (or fault system) is compressional during the interseismic period. From the focal mechanism of the crustal normal fault, two nodal planes exists, one east vergent and the other west vergent. The conceptual model in Hicks and Rietbrock (2015) shows that the true fault was the east vergent and that the activity of such a fault can generate vertical movements on the sea bottom ranging $0.3-0.7 \mathrm{~m}$, and only if a $\mathrm{Mw}=7$ event is of pure normal faulting, the vertical displacement increases to $1.2 \mathrm{~m}$. Our interpretation is that the crustal fault with normal movement is the Tirúa-Mocha splay fault that had tectonic inversion during the Araucanía 2011 earthquake, and thrust movement during the 1960-2010 interseismic period and Maule 2010 earthquake. This is also supported by the models of splay fault activity (Li et al., 2014) in which normal reactivation of a splay fault occur when the thrust movement centroid along WadatiBenioff plane is shallower than the root of the splay fault, condition that can be seen in figure 10F. For the 
crustal normal fault of Araucanía 2011 earthquake, we chose the west vergent fault, unlike Hicks and Rietbrock (2015). We asses that, in order for the east vergent fault to be normal and given its trace is located close to the eastern coast of Mocha Island, that place must have subsidence and Tirúa uplift, while the opposite occurred (Fig. 11D).

If the Tirúa-Mocha Splay fault existed before Valdivia 1960 earthquake it was not active during 1960 earthquake (Fig 11A) and considering the last seismic cycle 1960-2010, it was active during that time explaining the permanence of the 1960 coseismic uplift in Mocha Island until the Maule 2010 earthquake and the big interseismic uplift at Tirúa (Fig. 11B). The interplate convergence was accommodated partially by the development of the Tirúa-Mocha splay fault that branched from Wadati-Benioff plane at $35 \mathrm{~km}$ depth. That fault propagated upward at $45^{\circ}$ with west vergence. This is the same mechanism of development of splay faults in subduction zones and its activity in the subduction seismic cycle indicated by Fukao (1979), Cummins et al. (2001), Wendt et al. (2009), Tamura and Ide (2011), De Dontney and Hubbard (2012), and Li et al. (2014). The tip point of Tirúa-Mocha splay fault did not reached the sea bottom between Tirúa and Mocha Island during the 1960-2010 interseismic period (Fig. 11B) being a blind fault (Model $\mathrm{C}$ indicated $10 \mathrm{~km}$ depth for the tip point), and the interseismic crustal deformation must be an antiform fault propagation fold (or transient surface warping) associated with the Tirúa-Mocha splay fault. The existence of this fold is favoured by the interseismic tidal and GPS data (Nelson and Manley, 1992; Moreno et al., 2011). Thus, a highly coupled zone is surrounded by the Wadati-Benioff plane at the bottom, the sea bottom in the top, the trench in the west, and the Tirúa-Mocha splay fault to the east. They constitute a rocky block in the overriding plate with accretionary wedge shape. We name this block as Mocha block because includes Mocha Island (Fig. 11B, C and D). The horizontal

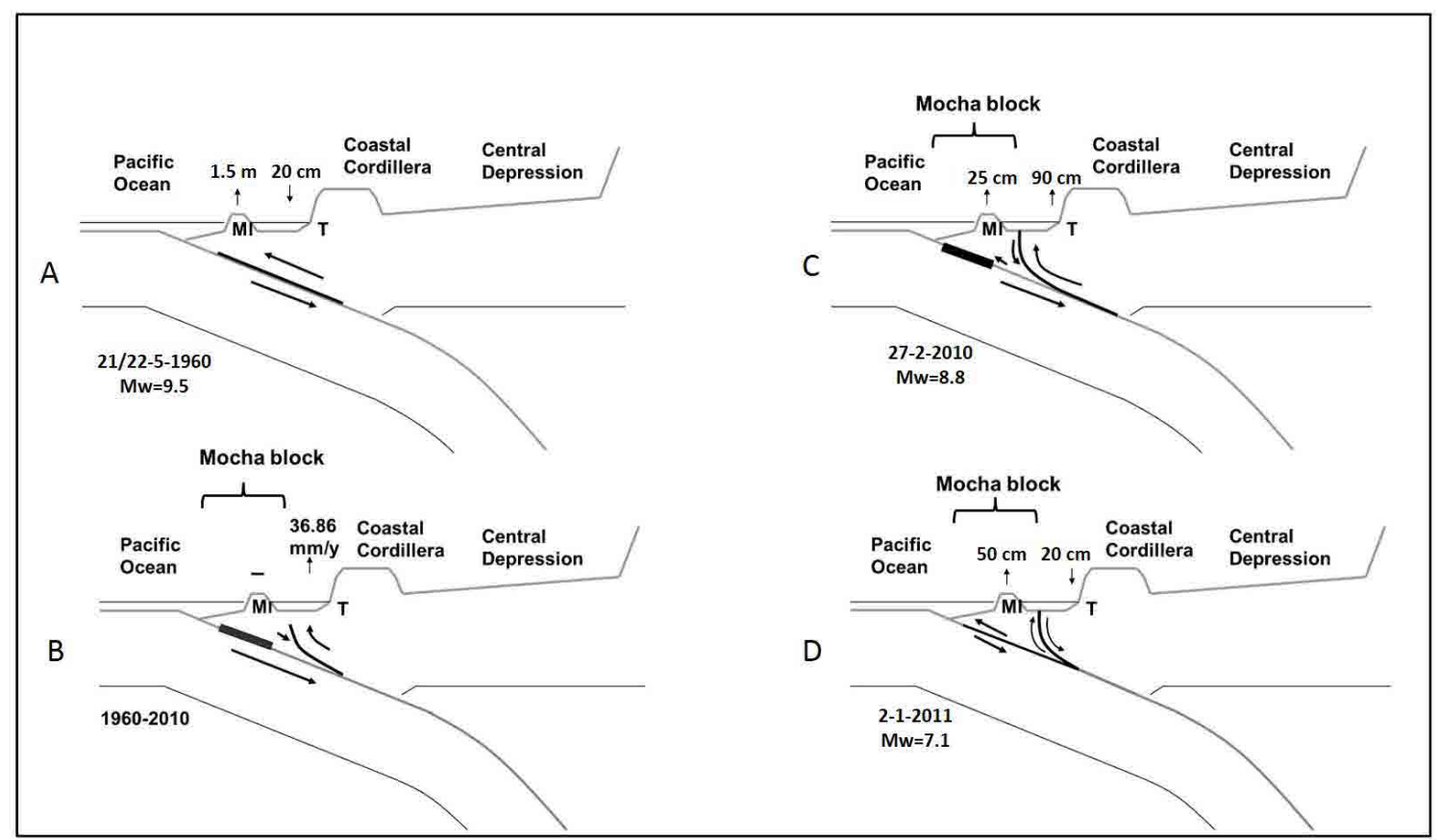

FIG. 11. Tectonic evolution of the Tirúa-Mocha Island zone in the last seismic cycle. A. 1960 coseismic movement along Wadati-Benioff plane. B. 1960-2009 interseismic movement. Strong asperity along the up dip of Wadati-Benioff zone (black rectangle), development of Mocha-Tirúa splay fault, vertical stability at Mocha Island and big uplift at Tirúa. C. Maule earthquake coseismic movement. Main slip along Tirúa-Mocha splay fault. Strong asperity (black rectangle) remained at the up dip of Wadati-Benioff plane. D. Removal of that asperity during the Araucanía 2011 earthquake, thrust movement at updip of WadatiBenioff plane and normal reactivation of Tirúa-Mocha splay fault. Mocha block is displayed. T: Tirúa, MI: Mocha Island. 
maximum stress $\sigma 1$ must be compressive between Tirúa and Mocha Island in the overriding plate.

We speculate that a strong asperity was developed after the Valdivia 1960 earthquake at the updip of Wadati-Benioff plane at Tirúa-Mocha area, generating strong coupling and the activity of the Tirúa-Mocha splay fault. During 2010 Maule earthquake, such asperity remained arresting the trenchward coseismic movement of South American plate, generating local compression accommodated by the Tirúa-Mocha splay fault and Mocha block remained coupled (Fig. 11C). So high stress continued in this zone until the Araucanía 2011 earthquake in which the asperity was finally overcome and the Tirúa Mocha splay fault had tectonic inversion with normal movement and Mocha block moved trenchward (Fig. 11D). Finally the seismic activity of moderate magnitude in the Tirúa-Mocha zone ended after Araucanía 2011 earthquake indicating that the main amount of stress accumulation at Tirúa-Mocha area was released.

\section{Conclusion}

The Tirúa-Mocha Island area of south Chile had an abnormal seismic cycle with two mega-earthquakes in only 50 years: Valdivia $1960 \mathrm{Mw}=9.5$ and Maule $2010 \mathrm{Mw}=8.8$ earthquake, with unexpected vertical interseismic ground movements and 2010 coseismic movements. During the 1960 Valdivia earthquake occurred normal vertical coseismic trend where Mocha Island experienced uplift and Tirúa subsidence, so slip occurred only along Wadati-Benioff zone. Then a net vertical interseismic stability at Mocha Island took place that contrasts with the interseismic subsidence at Santa María Island and Arauco Peninsula located northward of Mocha Island. Also Tirúa experienced the biggest interseismic uplift in all the rupture zone of the following Maule 2010 earthquake. Such anomalies are due to the existence and activity of the Tirúa Mocha splay fault.

During the Maule 2010 earthquake Tirúa experienced higher uplift than Mocha Island, in contrast with what occurred during the 1960 earthquake. This unexpected behaviour can be explained by the existence and slip of a splay fault located between Tirúa and Mocha Island (Tirúa-Mocha splay fault).

During 2011 Araucanía earthquake, the main slip occurred at the updip of Wadati-Benioff plane and the Tirúa-Mocha splay fault might have experienced tectonic inversion with normal activity.

\section{Acknowledgements}

This research was supported by the Dirección de Investigación of the Universidad de Concepción, projects DIUC N ${ }^{\circ}$ 207025036-1.0 and DIUC N $209603010-1.0$. A reviewer and the editor helped to improve the manuscript.

\section{References}

Angermann, D.; Klotz, J.; Reigber, C. 1999. Space-geodetic estimation of the Nazca-South America Euler vector. Earth Planet Science Letters 171 (3): 329-334.

Barrientos, S.; Ward, S. 1990. The 1960 Chile earthquake: inversion for slip distribution from surface deformation. Geophysical Journal International 103 (3): 589-598.

Bustamante, L.; Valenzuela, C. 2010. Lebu: minería del carbón y evolución urbana desde 1862 a la actualidad. Urbano 13 (21): 5-19.

Castilla, J.; Manríquez, P.; Camaño, A. 2010. Effects of rocky shore coseismic uplift and the 2010 Chilean mega-earthquake on intertidal biomarker species. Marine Ecology Progress Series 418: 17-23.

Chapman, J.; Elliott, J.; Doser, D.; Pavlis, T. 2014. Slip on the Suckling Hills splay fault during the 1964 Alaska earthquake. Tectonophysics 637: 191-197.

Cifuentes, I. 1989. The 1960 Chilean Earthquakes. Journal of Geophysical Research 94 (B1): 665-680.

Collot, J.; Agudelo, W.; Ribodetti, A.; Marcaillou, B. 2008. Origin of a crustal splay fault and its relation to the seismogenic zone and underplating at the erosional north Ecuador-south Colombia oceanic margin. Journal of Geophysical Research 113: B12102. doi: 10.1029/2008JB005691.

Cummins, P.; Hori, T.; Kaneda, Y. 2001. Splay fault and megathrust earthquake slip in the Nankai Trough. Earth Planets Space 53: 243-248.

De Dontney, N.; Hubbard, J. 2012. Applying Wedge Theory to Dynamic Rupture Modeling of Fault Junctions. Bulletin of the Seismological Society of America 102 (4): 1693-1711.

Delouis, B.; Nocquet, J-M.; Vallée, M. 2010. Slip distribution of the February 27, 2010 Mw = 8.8 Maule earthquake, central Chile, from static and high-rate GPS, InSAR, and broadband teleseismic data. Geophysical Research Letters 37 (17): L17305. doi: 10.1029/2010GL043899.

Farías, M.; Vargas, G.; Tassara, A.; Carretier, S.; Baize, S.; Melnick, D.; Bataille, K. 2010. Land-Level Changes Produced by the Mw 8.82010 Chilean Earthquake. Science 329: 916 p.

Fitz-Roy, R. 1839. Proceedings of the second expedition, 1831-1836, under the command of Captain Robert 
FitzRoy. In Narrative of the surveying voyages of His Majesty's ships Adventure and Beagle between the years 1826 and 1836, describing their examination of the southern shores of South America, and the Beagle's circumnavigation of the globe (Colburn, H.; editor). London, UK; reprint 1966, Abrahams Magazine Service, AMS Press: 695 p. New York.

Fritz, H.; Petroff, C.; Catalán, P.; Cienfuegos, R.; Winckler, P.; Kalligeris, N.; Weiss, R.; Barrientos, S.; Meneses, G.; Valderas-Bermejo, C.; Ebeling, C.; Papadopoulos, A.; Contreras, M.; Almar, R.; Domínguez, J.; Synolakis, C. 2011. Field Survey of the 27 February 2010 Chile Tsunami. Pure and Applied Geophysics 168. doi: 10.1007/s00024-011-0283-5.

Fukao, Y. 1979. Tsunami earthquakes and subduction processes near deep-sea trenches. Journal of Geophysical Research 84 (B5): 2303-2314.

Gulick, S.; Bangs, N.; Moore, G.; Ashi, J.; Martin, K.; Sawyer, D.; Tobin, H.; Kuramoto, S.; Taira, A. 2010. Rapid forearc basin uplift and megasplay fault development from 3D seismic images of Nankai Margin off Kii Peninsula, Japan. Earth and Planetary Science Letters 300: 55-62.

Hayes, G.; Bergman, E.; Johnson, K.; Benz, H.; Brown, L.; Meltzer, A. 2013. Seismotectonic framework of the 2010 February 27Mw 8.8 Maule Chile earthquake sequence. Geophysical Journal International 195 (2). doi: $10.1093 /$ gji/ggt238.

Heidarzadeh, M. 2011. Major Tsunami Risks from Splay Faulting. In Environmental Sciences, The Tsunami Threat - Research and Technology (Marner, N.A.; editor). InTech Europe: 67-80. Rijeka.

Hicks, S.; Rietbrock, A. 2015. Seismic slip on an upperplate normal fault during a large subduction megathrust rupture. Nature Geoscience 8: 955-960.

Hoechner, A.; Babeyko, A.; Sobolev, S. 2008. Enhanced GPS inversion technique applied to the 2004 Sumatra earthquake and tsunami. Geophysical Research Letters 35: L08310. doi:10.1029/2007GL033133.

Hollingsworth, J.; Ye, L.; Avouac, J.P. 2017. Dynamically triggered slip on a splay fault in the Mw 7.8, 2016 Kaikoura (New Zealand) earthquake. Geophysical Research Letters 44: 3517-3525.

Kiser, E.; Ishii, M. 2013. The 2010 Maule, Chile, Coseismic Gap and Its Relationship to the 25 March $2012 \mathrm{Mw}$ 7.1 Earthquake. Bulletin of the Seismological Society of America 103 (2A): 1148-1153.

Lange, D.; Tilmann, F.; Barrientos, S.; Contreras-Reyes, E.; Methe, P.; Moreno, M.; Heit, B.; Agurto, H.; Bernard, P.; Vilotte, J.-P.; Beck, S. 2012. Aftershock Seismicity of the 27 February 2010 Mw 8.8 Maule Earthquake Rupture Zone. Earth Planetary Science Letters 317318: 413-425.

Lay, T.; Ammon, C.; Kanamori, H.; Koper, K.; Sufri, O.; Hutko, A. 2010. Teleseismic inversion for rupture process of the 27 February 2010 Chile (Mw 8.8) earthquake. Geophysical Research Letters 37 (13). doi: 10.1029/2010GL043379.

Lee, C.; Tsu Chu, T.; Angelier, J.; Chang Chan, Y.; Hu, J.; Lu, C.; Rau, R. 2002. Geometry and structure of northern surface ruptures of the $\mathrm{Mw}=7.6 \mathrm{Chi}-\mathrm{Chi}$ Taiwan earthquake: influence from inherited fold belt structures. Journal of Structural Geology 24: 173-192.

Li, S.; Moreno, M.; Rosenau, D.; Melnick, D.; Oncken, O. 2014. Splay fault triggering by great subduction earthquakes inferred from finite element models. Geophysical Research Letters 41: 385-391. doi: 10.1002/2013GL058598.

Liberty, L.; Finn, S.; Haeussler, P.; Pratt, T.; Peterson, A. 2013. Megathrust splay faults at the focus of the Prince William Sound asperity, Alaska. Journal of Geophysical Research Solid Earth 118: 5428-5441. doi: 10.1002/jgrb.50372.

Melnick, D.; Cisternas, M.; Moreno, M.; Norambuena, R. 2012. Estimating coseismic coastal uplift with an intertidal mussel: calibration for the 2010 Maule Chile earthquake $(\mathrm{Mw}=8.8)$. Quaternary Science Reviews 42: 29-42.

Melnick, D.; Li, S.; Moreno, M.; Cisternas, M.; Jara, J.; Wesson, R.; Nelson, A.; Báez, J.; Deng, Z. 2018. Back to full interseismic plate locking decades after the giant 1960 Chile earthquake. Nature Communications 9 (3527). doi: 10.1038/s41467-018-05989-6.

Moore, G.; Bangs, N.; Taira, A.; Kuramoto, S.; Pangborn, E.; Tobin, T. 2007. Three-dimensional splay fault geometry and implications for tsunami generation. Science 318: 1128-1131. doi: 10.1126/science.1147195.

Moreno, M.; Melnick, D.; Rosenau.; Bolte, J.; Klotz, J.; Echtler, H.; Baez, J.; Bataille, K.; Chen, J.; Bevis, M.; Hase, H.; Oncken, O. 2011. Heterogeneous plate locking in the South-Central Chile subduction zone: Building up the next great earthquake. Earth and Planetary Science Letters 305 (3-4): 413-424.

Nelson, A.; Manley, W. 1992. Holocene coseismic and aseismic uplift of Isla Mocha, south central Chile. Quaternary International 15-16: 61-76.

Okada, Y. 1992. Surface deformation due to shear and tensile faults in a half-space. Bulletin of the Seismological Society of America 82 (2): 1018-1040. 
Ota, Y.; Yamaguchi, M. 2004. Holocene coastal uplift in the western Pacific Rim in the context of late Quaternary uplift. Quaternary International 120: 105-117.

Pizarro, J. 1991. Lebu: de la Leufumapu a su centenario 1540-1962. Editorial Ñielol: 398 p. Santiago.

Plafker, G. 1972. The Alaskan earthquake of 1964 and Chilean earthquake of 1960; Implications for arc tectonics and tsunami generation. Journal of Geophysical Research 77 (5): 901-925.

Plafker, G.; Savage, J. 1970. Mechanism of the Chilean Earthquakes of May 21 and 22, 1960. Geological Society of America Bulletin 81: 1001-1030.

Plafker, G.; Rubin, M. 1998. Uplift history and earthquake recurrence as deduced from marine terraces on Middleton Island, Alaska. In Proceedings of Conference VI, Methodology for identifying seismic gaps and soon-to-break gaps. U.S. Geological Survey OpenFile Report 78-943: 687-721. United States.

Plafker, G.; Savage, J. 2010. Near-Field Tsunami Characteristics of Giant Earthquakes in Chile (1960), Alaska (1964), and Sumatra (2004). U.S. Geological Survey Open-File Report: 2010-1152. U.S.A.

Plafker, G.; Ward, S.N.; Nishenko, S.P.; Cluff, L.S.; Coonrad, J.; Syahrial, D. 2007. Evidence for a secondary tectonic source for the cataclysmic tsunami of $12 / 26 / 2004$ on NW Sumatra, Seismological Society of America Annual meeting, Abstract. Kona.

Quezada, J.; Jaque, E.; Belmonte, A.; Fernández, A.; Vásquez, D.; Martínez, C. 2010. Movimientos cosísmicos verticales y cambios geomorfológicos generados durante el terremoto $\mathrm{Mw}=8,8$ del 27 de Febrero de 2010 en el centro-sur de Chile. Revista Geográfica del Sur 2: 11-44.

Quezada, J.; Jaque, E.; Fernández, A.; Vásquez, D. 2012. Cambios en el relieve generados como consecuencia del terremoto $\mathrm{Mw}=8,8$ del 27 de febrero de 2010 en el centro-sur de Chile. Revista de Geografía Norte Grande 53: 35-55.

Ramos, N.; Tsutsumi, H. 2010. Evidence of large prehistoric offshore earthquakes deduced from uplifted Holocene marine terraces in Pangasinan Province, Luzon Island, Philippines. Tectonophysics 495: 145-158.

Rietbrock, A.; Ryder, I.; Hayes, G.; Haberland, C.; Roecker, S.; Lyon-Caen, H. 2012. Aftershock seismicity of the 2010 Maule $\mathrm{Mw}=8.8$, Chile, earthquake: Correlation between coseismic slip models and aftershock distribution? Geophysical Research Letters 39: L08310.

Ruegg, J-C.; Rudloff, A.; Vigny, C.; Madariaga, R.; De Chabalier, J.; Campos, J.; Kausel, E.; Barrientos, S.; Dimitrov, D. 2009. Interseismic strain accumulation measured by GPS in the seismic gap between Constitución and Concepción in Chile. Physics of the Earth and Planetary Interiors 175: 78-85.

Saint Amand, P. 1961. Observaciones e interpretación de los terremotos chilenos de 1960. Universidad de Chile, Facultad de Ciencias Físicas y Matemáticas: 54 p. Santiago.

Savage, J.C.; Plafker, G.; Svarc, L.; Lisowski, M. 2014. Continuous uplift near the seaward edge of the Prince William Sound megathrust: Middleton Island, Alaska. Journal of Geophysical Research: Solid Earth 119 (7). doi: 10.1002/2014JB011127.

Shyu, B.; Wang, C.; Wang, Y.; Chiang, H.; Shen, C.; Thura Tun, S. 2014. Upper-plate splay fault earthquakes recorded by uplifted coral microatolls on Ramree Island, the western coast of Myanmar (Burma). Geophysical Research Abstracts 16: EGU General Assembly: EGU2014-2526.

Sparkes, R.; Tilmann, F.; Hovius, N.; Hillier, J. 2010. Subducted seafloor relief stops rupture in South American great earthquakes: Implications for rupture behaviour in the 2010 Maule, Chile earthquake. Earth and Planetary Science Letters 298 (1-2): 89-94. doi: 10.1016/j.eps1.2010.07.029.

Strasser, M.; Moore, G.; Kimura, G.; Kitamura, Y.; Kopf, A.; Lallemant, S.; Park, J.; Screaton, E.; Su, X.; Underwood, M.; Zhao, X. 2009. Origin and evolution of a splay fault in the Nankai accretionary prism. Nature Geoscience 2: 648-652.

Tamura, S.; Ide, S. 2011. Numerical study of splay faults in subduction zones: The effects of bimaterial interface and free surface. Journal of Geophysical Research 116: B10309. doi: 10.1029/2011JB008283.

Tiberti, M.; Basili, R.; Vannoligrecia, P. 2014. Ups and downs in western Crete (Hellenic subduction zone). Scientific Reports 4: 5677. doi: 10.1038/srep05677.

Tichelaar, B.; Ruff, L. 1991. Seismic coupling along the Chilean subduction zone. Journal of Geophysycal Research 96 (B7): 11997-12002.

Tong, X.; Sandwell, D.; Luttrell, K.; Brooks, B.; Bevis, M.; Shimada, M.; Foster, J.; Smalley, R.; Parra, H.; Báez, J.; Blanco, M.; Kendrik, E.; Genrich, J.; Caccamise, D. 2010. The 2010 Maule, Chile earthquake: Downdip rupture limit revealed by space geodesy. Geophysical Research Letters 37 (24). doi: 10.1029/2010GL045805.

Vargas, G.; Farías, M.; Carretier, S.; Tassara, A.; Baize, S.; Melnick, D. 2011. Coastal uplift and tsunami effects associated to the $2010 \mathrm{Mw} 8.8$ Maule earthquake in Central Chile. Andean Geology 38 (1): 219-238. 
Veyl, C.1960. Los fenómenos volcánicos y sísmicos de fines de mayo de 1960 en el sur de Chile. Universidad de Concepción, Instituto Central de Química, Departamento de Geología y Mineralogía: 42 p. Concepción.

Vigny, C.; Socquet, A.; Peyrat, S.; Ruegg, J.C.; Métois, M.; Madariaga, R.; Morvan, S.; Lancieri, M.; Lacassin, R.; Campos, J.; Carrizo, D.; Bejar-Pizarro, M.; Barrientos, S.; Armijo, R.; Aranda, C.; Valderas-Bermejo, M.C.; Ortega, I.; Bondoux, F.; Baize, S.; Lyon-Caen, H.; Pavez, A.; Vilotte, J.P.; Bevis, M.; Brooks, B.; Smalley, R.; Parra, H.; Baez, J.C.; Blanco, M.; Cimbaro, S.; Kendrick, E. 2011. The $2010 \mathrm{Mw} 8.8$ Maule Mega-Thrust Earthquake of Central Chile, Monitored by GPS. Science 332 (6036): 1417-1421. doi: 10.1126/science.1204132.

Wadhauser, F.; Schaff, D.; Diehl, T.; Engdahl, R. 2012. Splay faults imaged by fluid-driven aftershocks of the $2004 \mathrm{Mw} 9.2$ Sumatra-Andaman earthquake. Geology 40: 243-246.

Wang, T.; Wei, S.; Shia, X.; Qiu, Q.; Lia, L.; Peng, D.; Weldon, R.; Barbotab, S. 2018. The 2016 Kaikōura earthquake: Simultaneous rupture of the subduction interface and overlying faults. Earth and Planetary Science Letters 482 (15): 44-51.

Wendt, J.; Oglesby, D.; Geist, E. 2009. Tsunamis and splay fault dynamics. Geophysical Research Letters 36: L15303. doi: 10.1029/2009GL038295.

Wesson, R.; Melnick, D.; Cisternas, M.; Moreno, M.; Ely, L. 2015. Vertical deformation through a complete seismic cycle at Isla Santa María, Chile. Nature Geoscience 8: 547-553. doi: 10.1038/NGEO2468.

Xue, Y.; Liu, J.; Gang, L. 2010. Characteristics of seismic activity before Chile Mw 8.8 earthquake in 2010. Earthquake Science 23: 333-341.

Manuscript received: April 17, 2017; revised/accepted: September 5, 2019; available online: January 31, 2020. 